\title{
Intrakranijinių meningiomų radiologinių požymių ir jų histologinès diferenciacijos sąsajos: klinikinis atvejis ir literatūros apžvalga
}

\section{R. Montvilaitė*}

S. R. Letautiené $\dot{*}^{* *}$

R. Kvaščevičius***

A. Barkauskiené $\dot{e}^{* * * *}$

*Vilniaus universiteto ligoniné Santaros klinikos, Radiologijos ir branduolines medicinos centras

**Nacionalinis véžio institutas, Diagnostines ir intervencinès radiologijos skyrius

***Vilniaus universiteto Medicinos fakulteto Klinikinès medicinos institutas, Neurologijos ir neurochirurgijos klinika, Vilniaus universiteto ligonine Santaros klinikos, Neurochirurgijos skyrius $* * * *$ Vilniaus universiteto ligonine Santaros klinikos, Radiologijos ir branduolines medicinos centras

\begin{abstract}
Santrauka. Meningioma - dažniausiai pasitaikantis ne glijos kilmės centrinės nervų sistemos navikas. Dauguma jų būna nepiktybinès, tačiau apie 20 \% pasižymi mažesniu ląstelių diferenciacijos laipsniu, agresyvesne ligos eiga ir laikomos piktybinèmis. Kadangi nepiktybinių ir piktybinių meningiomų stebėjimo bei gydymo taktika skiriasi, svarbu kuo anksčiau minètus tipus atskirti. Remiantis radiologiniais vaizdais (kompiuterinès tomografijos, magnetinio rezonanso tomografijos), sunku prognozuoti meningiomos histologinę diferenciaciją, tačiau kai kurie požymiai leidžia ịtarti naviką esant piktybinị. Šiame straipsnyje pristatomas recidyvavusios piktybinès intrakranijinės meningiomos klinikinis atvejis ir literatūros apžvalga, analizuojamos meningiomų radiologinių požymių koreliacijos su naviko histologine diferenciacija.
\end{abstract}

Raktažodžiai: meningioma, kompiuterinè tomografija, magnetinio rezonanso tomografija, histologija.

\section{IVADAS}

Meningioma - dažniausiai pasitaikantis ne glijos kilmès centrinès nervų sistemos navikas suaugusiesiems (sudaro 16-20 \% visų intrakranijinių navikų) [1]. Dauguma šių navikuc - asimptomiai ir nustatomi atsitiktinai, tačiau dèl ap-

\footnotetext{
Adresas:

Rüta Montvilaitè

Vilniaus universiteto ligonine Santaros klinikos,

Radiologijos ir branduolines medicinos centras

Santariškiu g. 2, LT-08661 Vilnius

El.paštas ruta.mont@gmail.com
}

linkinių galvos smegenų struktūrų pažeidimo gali išsivystyti ịvairūs klinikiniai simptomai. Meningiomos paprastai diagnozuojamos vyresnio amžiaus žmonėms (didžiausias dažnis 60-80 m. amžiaus grupejje) [2]. Kadangi šiuolaikinei visuomenei būdinga populiacijos senèjimo tendencija ir ateityje vyresnio amžiaus žmonių dalis joje didès, taip pat dèl vis didejjančio atliekamų radiologinių tyrimų skaičiaus, tikètina, kad daugès ir meningiomų diagnozavimo atvejų.

Dauguma meningiomų - nepiktybinès, tačiau apie $20 \%$ pasižymi mažesniu ląstelių diferenciacijos laipsniu, agresyvesne ligos eiga ir laikomos piktybinemis [3]. Pastarosios greičiau auga, dažniau recidyvuoja, retais atvejais

(C) Neurologijos seminarai, 2020. Open Access. This article is distributed under the terms of the Creative Commons Attribution 4.0 International License CC-BY 4.0 (http://creativecommons.org/licenses/by/4.0/), which permits unrestricted use, distribution, and reproduction in any medium, provided you give appropriate credit to the original author(s) and the source, provide a link to the Creative Commons license, and indicate if changes were made. 
gali metastazuoti. Tam tikri kompiuterinès tomografijos (KT) ir magnetinio rezonanso tomografijos (MRT) tyrimu vaizduose matomi požymiai koreliuoja su meningiomos histologinès diferenciacijos laipsniu ir padeda jị prognozuoti [4]. Kadangi nepiktybinių ir piktybinių meningiomų stebejimo bei gydymo taktika skiriasi, svarbu kuo anksčiau minètus tipus atskirti.

Šiame straipsnyje pristatomas recidyvavusios piktybinès intrakranijinès meningiomos klinikinis atvejis ir literatūros apžvalga, analizuojamos meningiomų radiologinių požymių koreliacijos su naviko histologine diferenciacija.

\section{KLINIKINIS ATVEJIS}

78 metų moteris kreipèsi ị Vilniaus universiteto ligoninės Santaros klinikų (VULSK) Prièmimo-skubios pagalbos skyrių dèl staiga prasidejjusio kairès plaštakos silpnumo ir tirpimo. Pacientė taip pat nurodè kelis ménesius trunkanti galvos skausmą pakaušio srityje. Objektyvaus ištyrimo metu kairẻje rankoje nustatyta sumažejjusi raumenų jẻga (distaliai 2-3 balai) ir sustiprèję sausgyslių refleksai. Kitose galūnėse raumenų jẻga buvo normali, patologinių, meninginių refleksų nenustatyta, galvinių nervų funkcija nesutrikusi. Gyvenimo anamnezè: galvos smegenų infarktu pacientė nesirgusi, jaunystejje patyrusi galvos traumą. Esant ūmiai židininei neurologinei simptomatikai, pacientė būtinajai pagalbai buvo hospitalizuota ị Nervų ligų skyrių ir dèl ịtariamų ūmių išeminių pakitimų jai paskirta galvos smegenų KT.

Galvos smegenų KT vaizduose ūmiai išemijai būdingų židininių pakitimų nebuvo matoma. Dešinès kaktinės skilties srityje konveksitaliai buvo matomas apie $51 \times 42 \times 20 \mathrm{~mm}$ dydžio ekstraaksialinis darinys, plačiu pagrindu kontaktuojantis su kietuoju smegenų dangalu. Natyviniuose vaizduose - darinys aiškiomis ribomis, hiperdensinis, kiek nehomogeniškos struktūros. Kontrastinę medžiagą $(\mathrm{k} / \mathrm{m})$ kaupe intensyviai, ne visai homogeniškai.

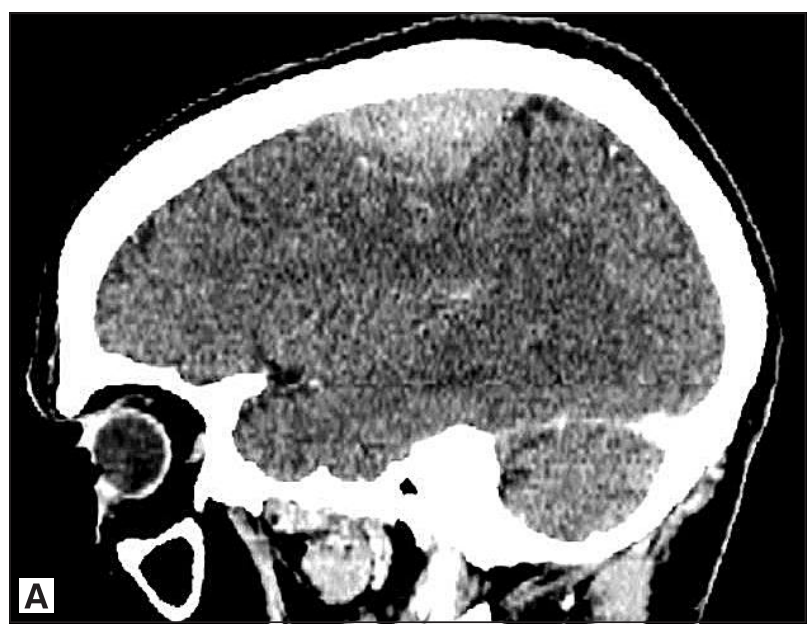

2 pav. Galvos KT su k/m vaizdai, sagitalinis (A) ir koronarinis (B) pjūviai.

Intensyvus, ne visai homogeniškas k/m kaupimas darinyje.
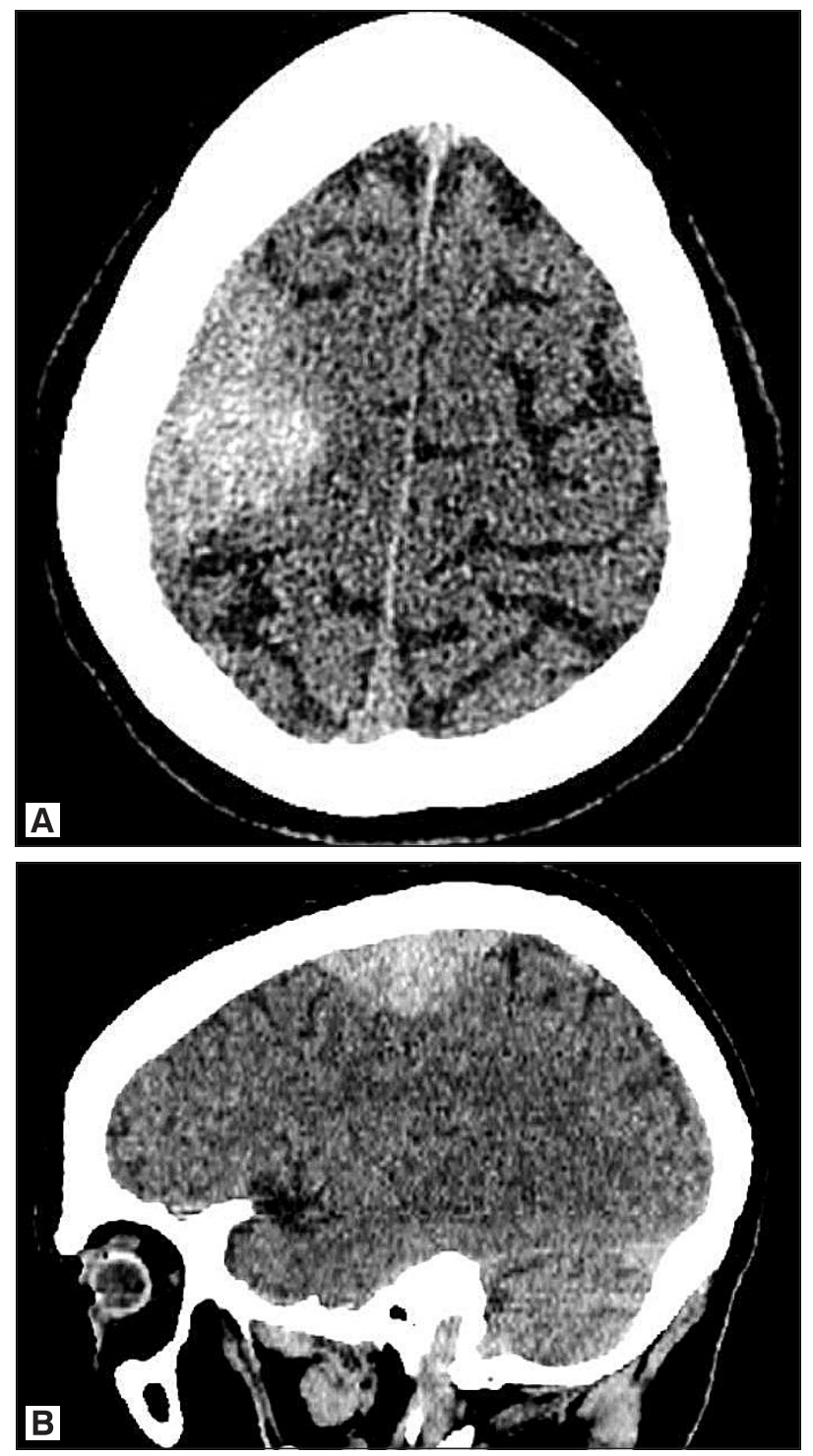

1 pav. Galvos KT natyviniai vaizdai, aksialinis (A) ir sagitalinis (B) pjūviai.

Dešinėje kaktinejje skiltyje konveksitaliai matomas aiškių ribų, hiperdensinis, kiek nehomogeniškos struktūros ekstraaksialinis darinys, plačiu pagrindu kontaktuojantis su kietuoju dangalu.

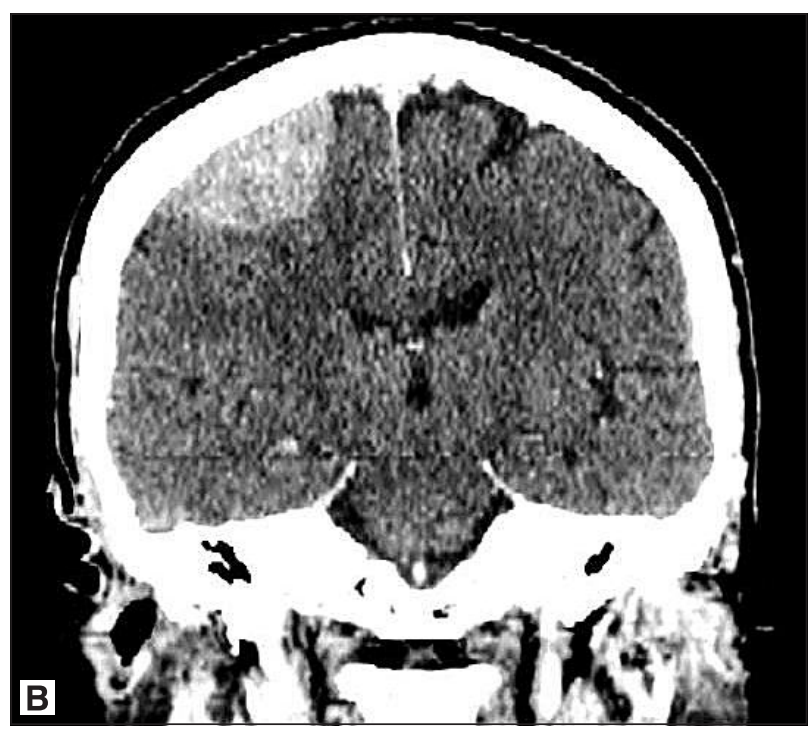



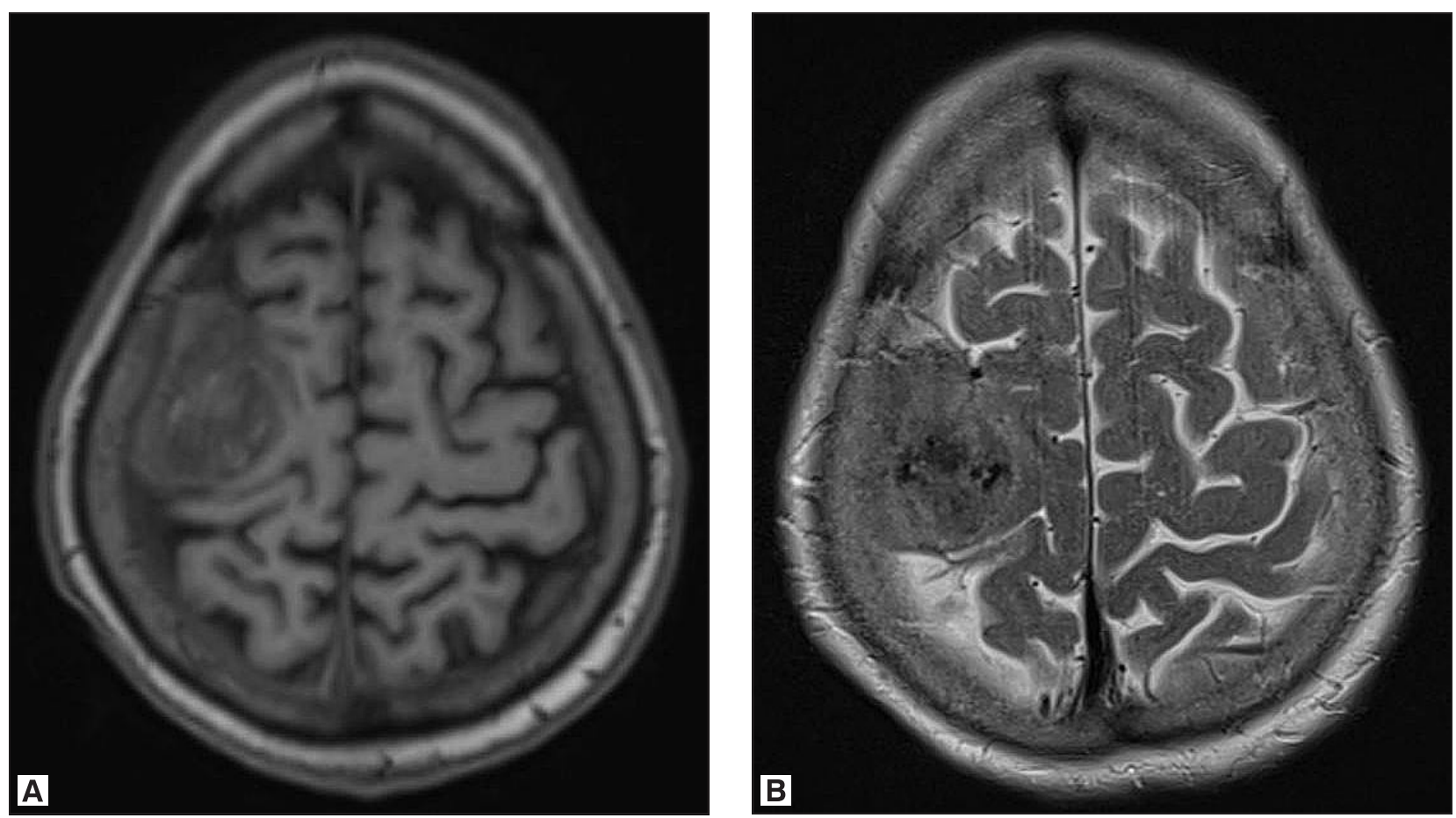

3 pav. Galvos MRT vaizdai, aksialiniai pjūviai.

Dešinėje kaktinejje skiltyje konveksitaliai matomas T1 sekoje (A) hipointensinio signalo su hiperintensiniais intarpais, T2 sekoje (B) izointensinio signalo su hipointensiniais intarpais darinys be perifokalinės edemos požymių.

Aplinkinio smegenų audinio edemos, patologinių kaulų pakitimų nebuvo matoma. Tyrimo išvada: dešinès kaktinès skilties srityje konveksitaliai meningiomai būdingas darinys (1, 2 pav.).

Pakitimams patikslinti pacientei buvo paskirta galvos smegenų MRT. Jos vaizduose dešinės kaktinès skilties srityje konveksitaliai buvo matomas apie $47 \times 25 \times 20 \mathrm{~mm}$ dydžio ekstraaksialinis darinys aiškiomis ribomis, dislokuo-

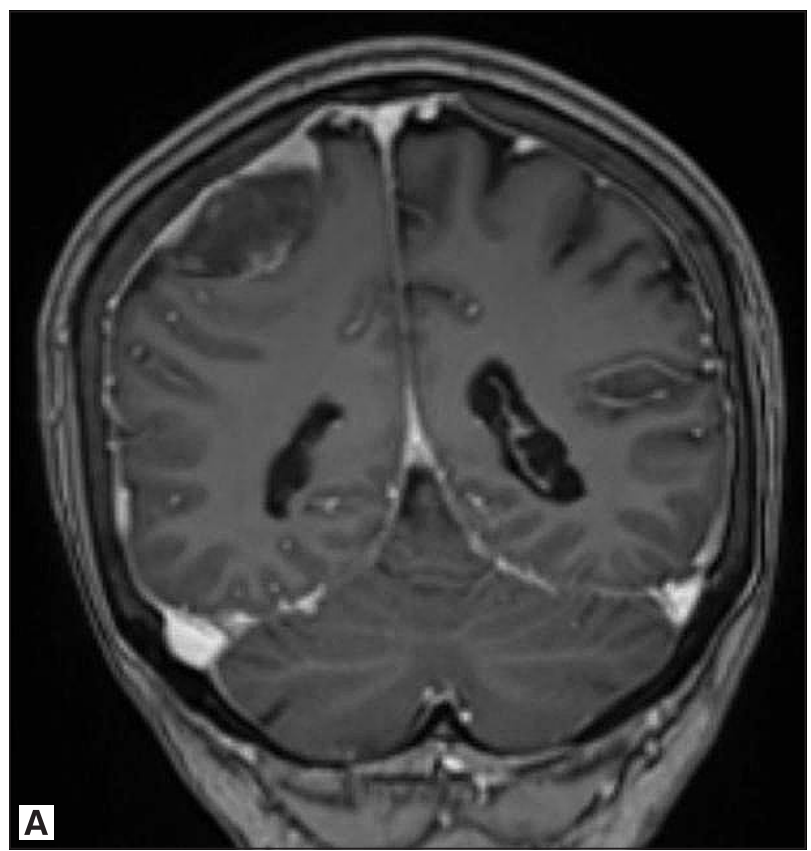

jantis aplinkinę smegenų parenchimą (priešcentrinio, viršutinio ir vidurinio kaktinių vingių) be jos edemos požymių. Darinys T1 sekoje - hipointensinio signalo su hiperintensiniais intarpais, T2 sekose - izointensinio signalo su hipointensiniais intarpais. Padidejusios difuzijos restrikcijos požymių nebuvo matoma. Darinys netolygiai kaupé k/m. Tyrimo išvada: dešinès kaktinès skilties srityje ekstraaksialinis darinys, būdingas meningiomai ( 3,4 pav.).

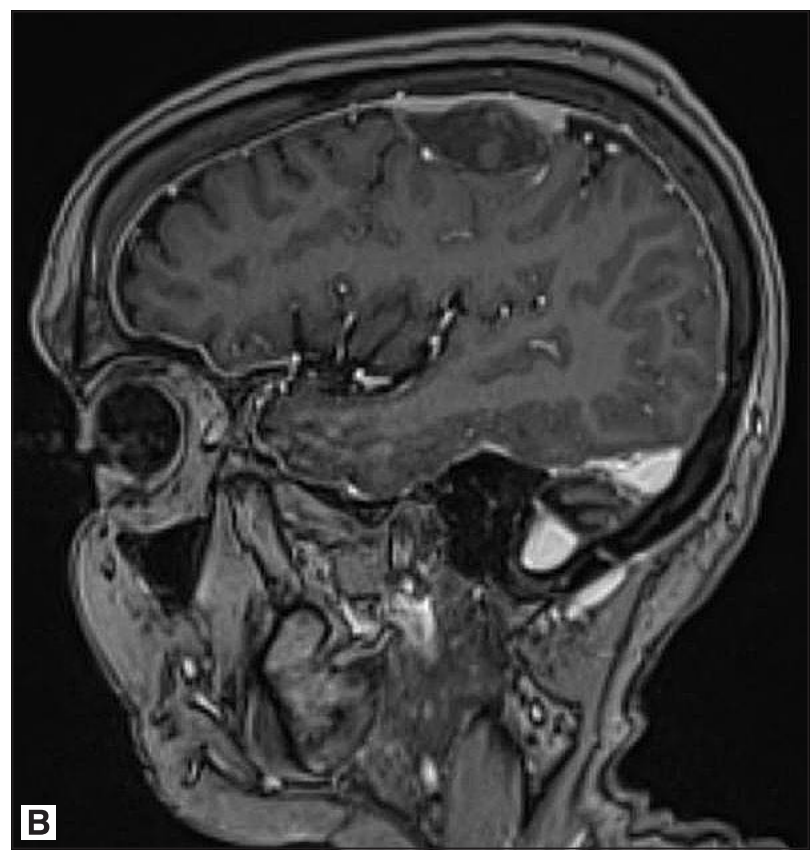

4 pav. Galvos MRT vaizdai, koronarinis (A) ir sagitalinis (B) pjūviai.

Darinys netolygiai kaupia k/m (T1 su k/m seka). 

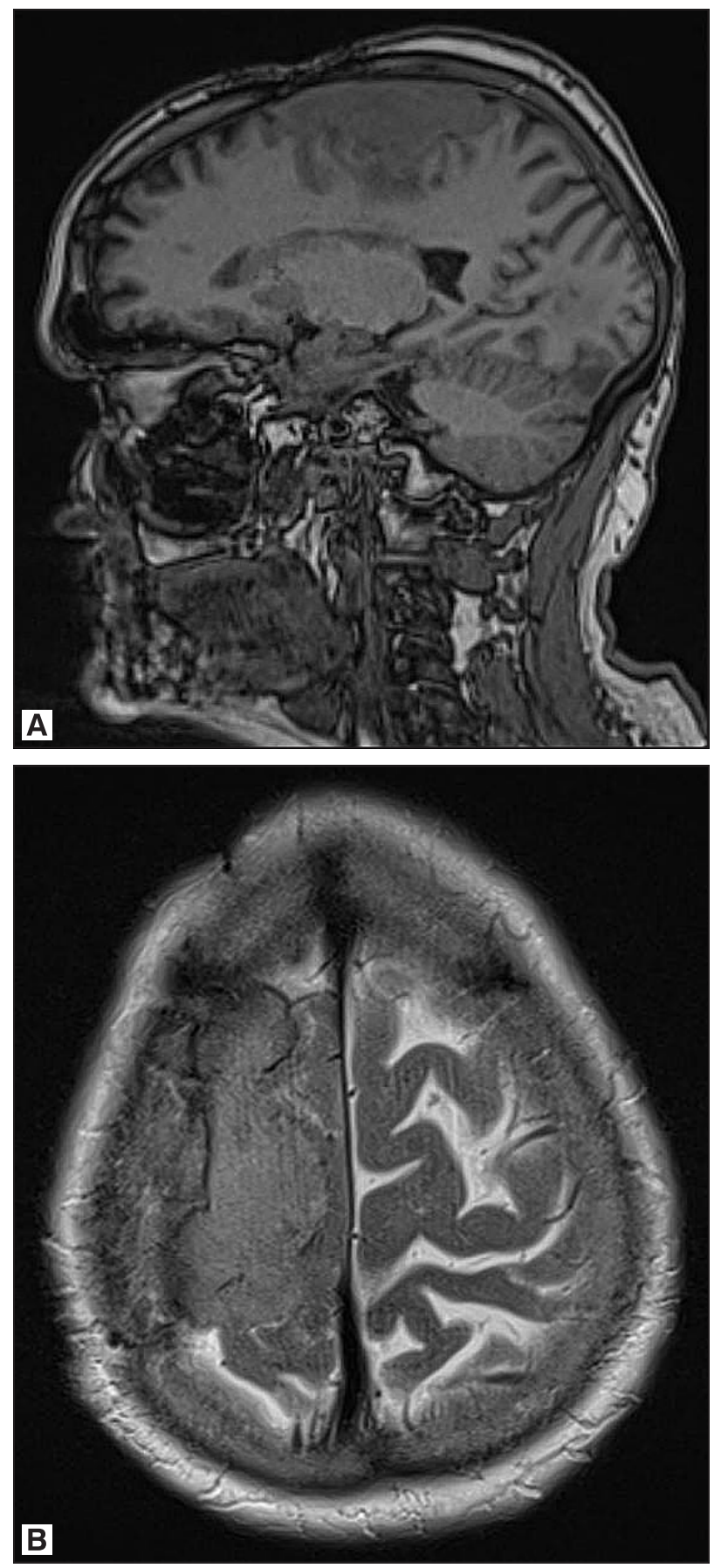

5 pav. Galvos MRT vaizdai, sagitalinis ir aksialinis pjūviai. Dešinejje frontoparietaliai matomas netaisyklingos formos, T1 sekoje (A) - hipointensinio signalo, T2 sekoje (B) - hiperintensinio signalo ekstraaksialinis darinys nelygiu kontūru, plačiu pagrindu kontaktuojantis su kietuoju dangalu.

Stacionarizavimo metu taikant konservatyvų gydymą (manitolio tirpalo intravenines injekcijas ir kitus pacientès vartojamus kardiologinius vaistus), kairès rankos silpnumas pacientei regresavo, išliko tik galvos skausmas. Nesant terapinių kontraindikacijų, pacientei buvo rekomenduotas naviko operacinis gydymas planine tvarka.

Po savaitès pacientė hospitalizuota operaciniam gydymui. Operacijos metu pašalinus naviką, jo audinio fragmentai išsiųsti histologiniam tyrimui. Galutinè patologijos
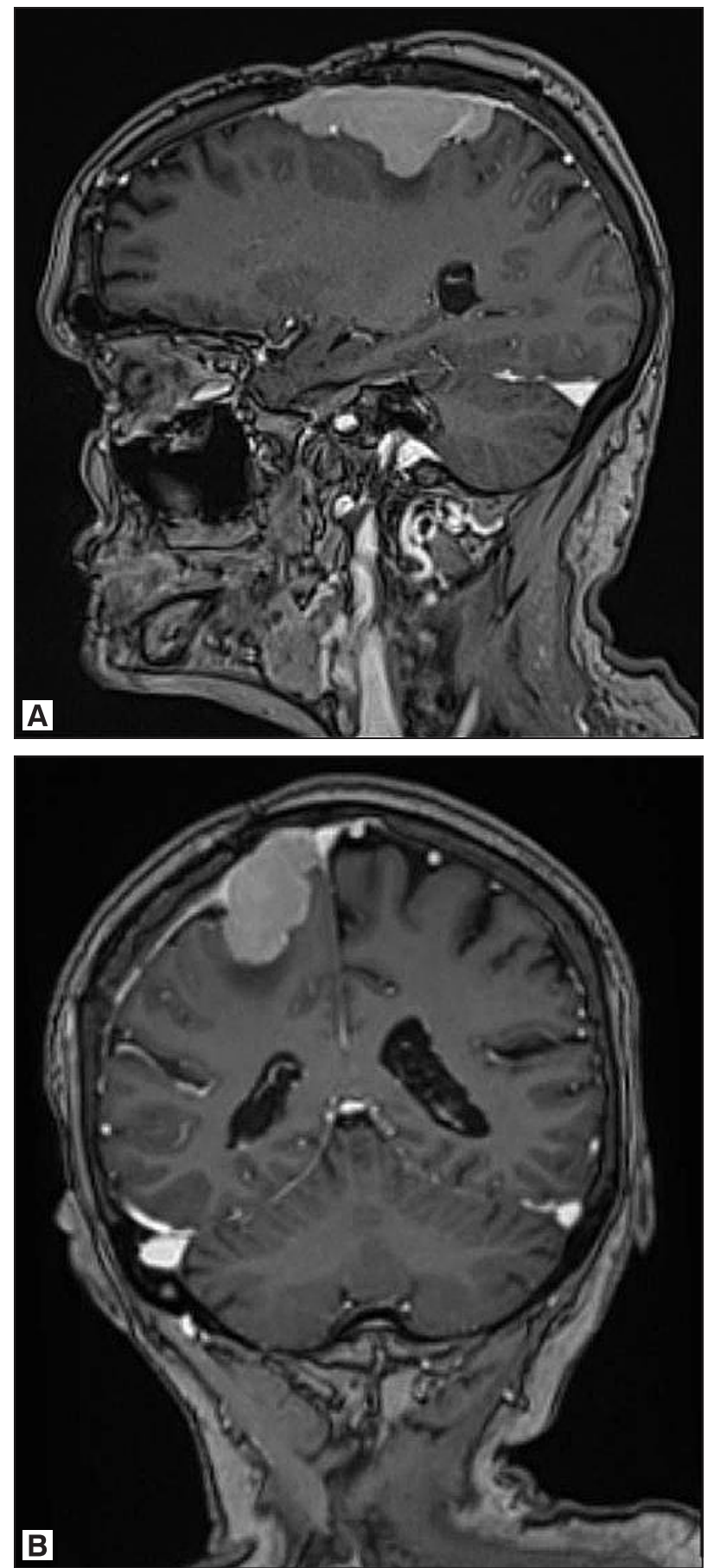

6 pav. Galvos MRT vaizdai, sagitalinis (A) ir koronarinis (B) pjūviai.

Darinys intensyviai, homogeniškai kaupia k/m ( $\mathrm{T} 1 \mathrm{su}$ k/m seka).

diagnozė buvo atipinė meningioma, G2. Pasaulio sveikatos organizacijos (PSO) klasifikacijoje šis histologinis variantas priskiriamas $\mathrm{II}^{\circ}$ pagal piktybiškumą.

Pooperacinis periodas praejo sklandžiai, stacionare atlikus reabilitaciją, pacientè buvo išrašyta, paskyrus galvos MRT kontrolinị tyrimą po 1 metų. Tačiau, nepraejjus šiam laikui (po 10 mėn.), pacientè kreipèsi ị II lygio stacionarą, iš kurio vėliau buvo nukreipta ị VULSK Prièmimo-skubios pagalbos skyrių dèl intensyvaus galvos skausmo (įvertinto 6 balais), kairès pusès galūnių nusilpimo, nega- 

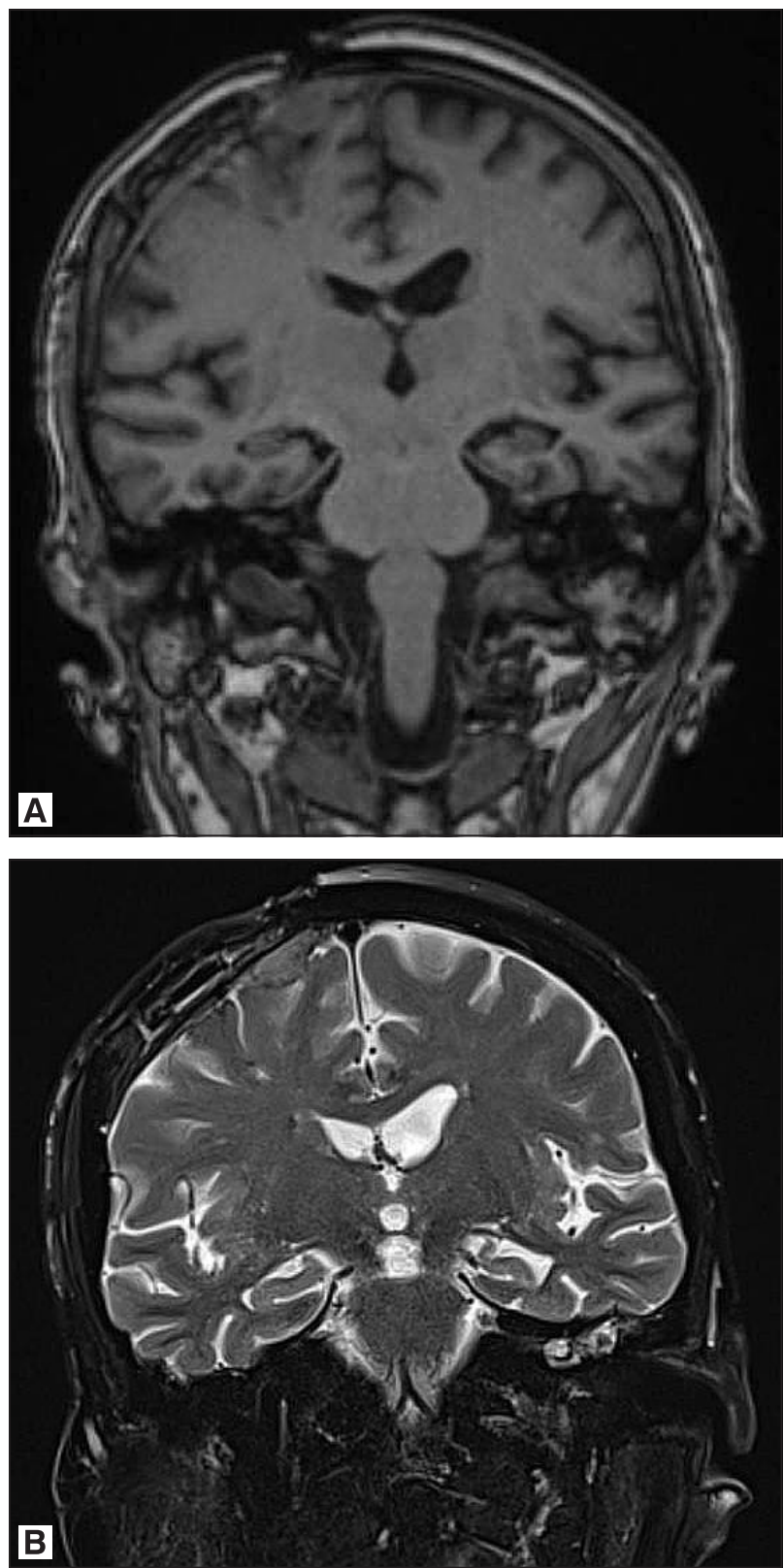

7 pav. Galvos MRT vaizdai, koronariniai pjūviai.

Dešinèje frontaliai prie kaulinio lopo matomas T1 (A) ir T2 (B) sekose izointensinis židinys, plačiu pagrindu kontaktuojantis su kietuoju dangalu, glaudžiai kontaktuojantis su viršutinio strèlinio ančio dešiniu kraštu be peraugimo požymių.

lëjimo paeiti. Galūnių nusilpimą pacientė pastebẻjo prieš 2 mènesius, jis palaipsniui stiprèjo. Objektyvaus ištyrimo metu stebėta ataksiška eisena, sumažejusi raumenų jèga kairèje rankoje (proksimaliai - 4, distaliai - 5 balai) bei kairejje kojoje (proksimaliai - 4, distaliai - 2 balai), kairejje rankoje sustiprėję sausgyslių refleksai. II lygio stacionare atliktoje galvos KT (buvo pateiktas tyrimo aprašymas): dešinèje frontoparietaliai sustorèję smegenų dangalai, matomas ekstraaksialinis hiperdensinis apie $69 \times 30 \mathrm{~mm}$ dydžio $\mathrm{k} / \mathrm{m}$ kaupiantis darinys skiltètu kontūru su nedidele kalcifikacija. Darinys sukelia nedidelę vidurio struktūrų dislokaciją ir perifokalinę edemą. Tyrimo išvada: darinys dešinėje frontoparietaliai, būdingas meningiomai.
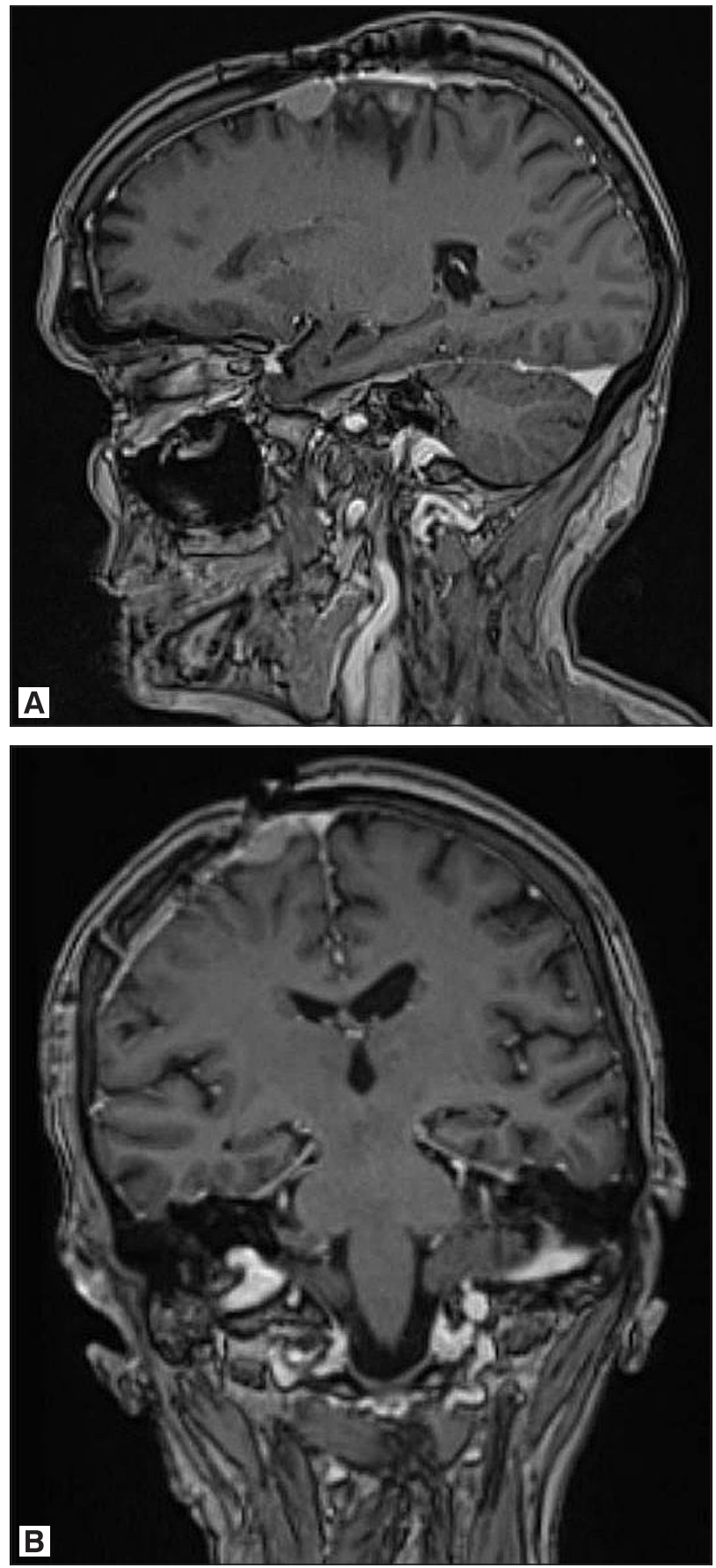

8 pav. Galvos MRT vaizdai, sagitalinis (A) ir koronarinis (B) pjūviai.

Židinys homogeniškai kaupia k/m (T1 su k/m seka).

Pacientè hospitalizuota ir pakitimams galvos smegenyse patikslinti paskirta MRT. Tyrimo vaizduose dešinejje frontoparietaliai operacinėje srityje (prie kaulinio lopo) buvo matomas apie $68 \times 31 \times 25 \mathrm{~mm}$ dydžio netaisyklingos formos ekstraaksialinis darinys nelygiu kontūru, gana homogeniškos struktūros, plačiu pagrindu kontaktuojantis su kietuoju dangalu. Darinys T1 sekoje - hipointensinio, T2 sekose - hiperintensinio signalo, homogeniškai kaupia k/m. Stebètas jo kontaktas su viršutinio strèlinio ančio dešiniu kraštu be peraugimo požymių, nedidelè aplinkinio smegenų audinio edema, dešinèje frontoparietaliai paly- 
ginti subarachnoidiniai konveksitaliniai tarpai. Vidurio linijos struktūros apie $3 \mathrm{~mm}$ dislokuotos ị kairę. Tyrimo išvada: būklè po atipinès meningiomos operacinio gydymo. Meningiomos recidyvas dešinejje frontoparietaliai operacinèje srityje (5, 6 pav.).

Pacientei rekomenduotas operacinis naviko gydymas. Operacijos metu navikas pašalintas makroskopiškai radikaliai, jo audinio fragmentai išsiųsti histologiniam tyrimui. Galutinè patologijos diagnozė: atipinè meningioma, G2 (PSO $\mathrm{II}^{\circ}$ histologinis variantas).

Po operacijos pacientei išliko kairès pusès galūnių parezė (rankoje proksimaliai - 2, distaliai - 1 balas, kojoje proksimaliai - 3, distaliai - 1-2 balai), tačiau pooperaciniu periodu ir reabilitacijos stacionare taikant reabilitacijos procedūras stebèta teigiama simptomų dinamika (galūnių jèga vertinta 4 balais).

Praèjus 1 mèn. po operacijos, atlikta kontrolinè galvos MRT, kurios vaizduose dešinėje frontaliai operacinèje srityje (prie kaulinio lopo) buvo matomas plačiu pagrindu su dangalais kontaktuojantis apie $16 \times 15 \times 8 \mathrm{~mm}$ dydžio T1 ir T2 sekose izointensinis židinys, homogeniškai kaupiantis k/m, glaudžiai kontaktuojantis su viršutinio strẻlinio ančio dešiniu kraštu be peraugimo požymių. Ties pooperacine lože stebèti seni kraujo produktai, žievę ir požievị apimanti T2 hiperintensinè zona, būdinga gliozei, lokaliai sustorèję ir intensyviau $\mathrm{k} / \mathrm{m}$ kaupiantys smegenų dangalai - pooperaciniai pakitimai. Tyrimo išvada: būklẻ po dešinės frontoparietalinès rekraniotomijos, atipinės meningiomos recidyvo šalinimo. Židinys ties kauliniu lopu, plačiu pagrindu kontaktuojantis su smegenų dangalais, - meningiomos recidyvas ar likutinis audinys (7, 8 pav.).

Kadangi stebėta pacientès neurologinès būklès teigiama dinamika, o MRT vaizdai neleido patikimai patvirtinti naviko recidyvo, chirurginis gydymas nebuvo indikuotinas, pacientė nukreipta tolimesniam spinduliniam gydymui į Nacionalinị vėžio institutą.

\section{LITERATŪROS APŽVALGA}

\section{Epidemiologija}

Meningioma yra dažniausiai pasitaikantis ne glijos kilmės centrinės nervų sistemos (CNS) navikas suaugusiesiems (sudaro 16-20\% visų intrakranijinių navikų) [1]. Jos paprastai diagnozuojamos vyresniems nei 30 metų asmenims ir dažnis didèja su amžiumi: amžiaus mediana diagnozavimo metu yra 64 metai. Tarp vaikų meningiomos tesudaro 1,9\% pirminių CNS navikų [4]. Vidutinio amžiaus grupèje (35-65 m.) visų diferenciacijos laipsnių meningiomos dažniau nustatomos moterims nei vyrams (santykis atitinkamai 2,2:1), o tarp vyresnių pacientų ( $\geq 75 \mathrm{~m}$.) piktybinès meningiomos dažniau diagnozuojamos vyrams (moterų ir vyrų santykis 0,8:1) [5].

Per pastaruosius kelis dešimtmečius meningiomų dažnis išsivysčiusiose šalyse padidejo - tai siejama su pagerè- jusiomis diagnostikos galimybėmis, tačiau ịtakos tam gali turèti ir aplinkos rizikos veiksniai (žr. skyrių „Etiologija ir rizikos veiksniai“) [4].

\section{Etiologija ir rizikos veiksniai}

Meningiomų etiologija nėra iki galo aiški. Tik jonizuojančiosios spinduliuotès poveikis ir kelios retos paveldimos būklès yra pripažinti rizikos veiksniais. Kiti veiksniai - egzogeniniai ir endogeniniai lytiniai hormonai, krūties vèžys, galvos trauma - literatūroje vertinami prieštaringai [4].

Tiek mažos (<10 Gy), tiek vidutinės (10-20 Gy) ar didelès (>20 Gy) jonizuojančiosios spinduliuotès dozès didina meningiomos išsivystymo riziką. Tai įrodė tyrimai, atlikti vertinant dantų rentgenogramų, radioterapijos galvos-kaklo srityje bei Hirošimos ir Nagasakio atominę katastrofą išgyvenusiųjų patirtos apšvitos poveikị. Nustatyta atvirkštinè priklausomybė tarp apšvitos dozės ir naviko formavimosi laiko: kuo didesnè dozè, tuo trumpesnis naviko išsivystymo laikas (atitinkamai 35, 26 ir 19-24 m. mažos, vidutinès ir didelès apšvitos atveju) [6].

II tipo neurofibromatozė yra reta autosominiu dominantiniu būdu paveldima liga, kuriai būdingas nepiktybinių navikų formavimasis centrinėje ir periferinėje nervų sistemoje. Apie $50 \%$ ja sergančiųų išsivysto meningiomos, kurios dažnai būna daugybinès. Navikų formavimąsi šios ligos atveju lemia NF2 geno 22 chromosomoje mutacija [4]. Manoma, kad šio geno mutacija lemia ir 50-80\% sporadinių meningiomų atvejų [7]. Taip pat pastebėta, kad meningiomos rizika asmeniui padidejja du kartus, jei ja sirgo pirmos eilès giminaitis (rizika tiesiogiai proporcinga sergančių giminaičių skaičiui) [4].

Keliose studijose rastas ryšys tarp meningiomos išsivystymo ir vèliau įvykusios menarchès (>14 m.) bei nėštumo, tačiau šiems rizikos veiksniams patvirtinti trūksta įrodymų [7]. Pomenopauzinè estradiolio terapija šiek tiek padidina meningiomos riziką, tačiau ryšys su peroralinių kontraceptikų vartojimu nėra statistiškai patikimas, jam įvertinti reikalingi tolesni tyrimai [4]. Meningiomos rizika yra didesnė krūties vėžiu sergančioms moterims ir atvirkščiai - pacientėms, kurioms diagnozuota meningioma, nustatyta didesnè krūties vėžio rizika. Manoma, kad ryši tarp šių patologijų lemia persidengiantys rizikos veiksniai [7].

Kai kuriuose atvejo-kontrolès tyrimuose aprašoma galvos traumos įtaka meningiomai išsivystyti, pasiūlyta hipotezè, kad naviko formavimąsi šiuo atveju lemia smegenų dangalų sudirginimas dèl lètinio uždegimo ir granuliomos atsiradimo traumos srityje. Tačiau kituose tyrimuose ryšys su galvos trauma neaptiktas, o įrodymai - nenuoseklūs [4].

\section{Klinikiniai aspektai}

Meningiomos dažnai būna asimptomès ir randamos atsitiktinai dèl kitos priežasties atlikto radiologinio tyrimo metu, tačiau, jei navikas sukelia greta esančios galvos smege- 
1 lentelè. Su kai kuriomis meningiomos lokalizacijomis siejami klinikiniai simptomai [2,9]

\begin{tabular}{|l|l||}
\hline \hline Naviko lokalizacija & Galimi klinikiniai simptomai \\
\hline Parasagitalinė & Priešingos pusės kojos monoparezė, traukuliai \\
\hline Subfrontalinė & Sąmonės ir kognityvinių funkcijų sutrikimas, apatija, šlapimo nelaikymas \\
\hline Pleištakaulio sparnai & Traukuliai, galvinių nervų paralyžiaus požymiai (jei ị procesą įtrauktas viršutinis akiduobės plyšys) \\
\hline Cerebelopontininis kampas & Susilpnėjusi klausa, kartu gali būti nejautra veido srityje ir veido raumenų silpnumas \\
\hline Akytasis antis & Daugybinė galvinių nervų (II-VI) disfunkcija, sukelianti regejjimo susilpnejjimą, diplopiją, veido nejautrą \\
\hline Turkiškasis balnas & Regėjimo lauko sutrikimas, regos netekimas \\
\hline $\begin{array}{l}\text { Uodžiamojo stormens } \\
\text { sritis }\end{array}$ & $\begin{array}{l}\text { Anosmija, kartu gali būti regos nervo atrofijos požymių ipsilateraliai ir papiledema kontralateraliai } \\
\text { (Kennedy-Foster sindromas) }\end{array}$ \\
\hline Foramen magnum & Pakaušio skausmas, paraparezė, sfinkterių disfunkcija, liežuvio atrofija \\
\hline \hline
\end{tabular}

2 lentelè. PSO meningiomu klasifikacija [28]

\begin{tabular}{|c|c|c|}
\hline PSO $\mathbf{I}^{\circ}$ & PSO II $^{\circ}$ & PSO III $^{\circ}$ \\
\hline Meningotelinè & Chordoidinè & Papilinė \\
\hline Fibrozinè & Šviesių ląstelių & Rabdoidinè \\
\hline Pereinamoji & Atipinè & Anaplazinè \\
\hline Psamomatozinè & • Padidèjęs mitozių skaičius (4-19/10 DPRL) & - Akivaizdūs citologiniai \\
\hline Angiomatozinè & - Invazija ị smegenų audinị & piktybiškumo požymiai (primenantys \\
\hline Mikrocistinè & · Bent 3 iš šių požymių: & karcinomą, melanomą, didelio \\
\hline Sekrecinė & - padidejęs ląstelių skaičius & . Ryškiai nadidejes mitoziu skaičius \\
\hline Limfoplazmocitinė & - mažos ląstelès su dideliu branduolio / citoplazmos santykiu & $\begin{array}{l}\text { - Ryskia1 padidejęs mitozių ska1cius } \\
(\geq 20 / 10 \text { DPRL) }\end{array}$ \\
\hline \multirow[t]{3}{*}{ Metaplazinè } & - ryškūs branduolèliai & \\
\hline & - netipinė audinio architektonika & \\
\hline & - spontaninės nekrozės židiniai & \\
\hline
\end{tabular}

DPRL - didelio padidinimo regéjimo laukas

nų žievès dirginimą, smegenų parenchimos ar galvinių nervų kompresiją, pažeidžia kraujagysles, gali atsirasti įvairių klinikinių simptomų. Tai daugiau būdinga didelès apimties meningiomoms, jų atveju pacientai dažniausiai skundžiasi galvos skausmu ir regejjimo sutrikimais (atitinkamai $45 \%$ ir $30 \%$ atvejų) [8]. Simptomai taip pat priklauso nuo naviko lokalizacijos, tačiau meningiomoms jie nèra specifiniai (1 lentelè) [9].

\section{Pasaulio sveikatos organizacijos klasifikacija}

Pasaulio sveikatos organizacijos (PSO) CNS navikų klasifikacijoje meningiomos pagal tokius histologinius kriterijus, kaip ląstelių tipas ir kiekis, mitotinis aktyvumas, nekrozè, smegenu audinio invazija, skirstomos ị tris laipsnius. Apie $80 \%$ meningiomų yra nepiktybinès ir priskiriamos I laipsniui (9 histologiniai variantai), likusi dalis (6 histologiniai variantai) pasižymi mažesniu ląstelių diferenciacijos laipsniu, agresyvesne ligos eiga ir laikomos piktybinèmis: tai II laipsnio - atipinès (apie $18 \%$ ) ir III laipsnio - anaplazinės (apie $2 \%$ ) meningiomos (2 lentelè) [3]. Piktybinès meningiomos greičiau auga, dažniau recidyvuoja, retais atvejais gali metastazuoti (dažniausiai ì plaučius ir intraabdominalinius organus) [8]. Jų stebėjimo ir gydymo taktika skiriasi nuo I laipsnio navikų, todèl yra svarbi ankstyva diagnostika.

\section{Radiologiniai požymiai}

Meningiomos kyla iš meningoepitelinių ląstelių, todèl paprastai išsivysto srityse, kur šių ląstelių yra daugiausia ties kietojo smegenų dangalo ančiais, kur gausu voratinklinio dangalo granuliacijų. Kitos galimos lokalizacijos - galvinių nervų išejjimo iš kaukolès vietos, kraujagyslių rezginys. Literatūroje apibendrinama, kad bet kuri meningoepitelinė ląstelè (esanti intrakranialiai, stuburo kanale ar ektopinė) yra potencialus meningiomos vystymosi šaltinis [2].

Dauguma meningiomų yra intrakranijiniai ekstraaksialiniai navikai. 20-34 \% jų nustatoma konveksitaliai (9 pav.), 18-22 \% - parasagitaliai, 17-25\% - ties pleištakaulių sparnais ir vidurinėje kaukolès duobėje, $10 \%$ frontobazaliai, 9-15\% - užpakalinėje kaukolès duobėje. 1-2 \% navikų auga intraventrikuliariai (10 pav.) ir akiduobėse. Nedidelè dalis meningiomų formuojasi iš kietojo smegenų dangalo stuburo kanale (apie $12 \%$ ) ir apie $1 \%$ yra ekstradurinès, nustatomos ektopinèse lokalizacijose kaukolès skliauto kauluose (11 pav.), prienosiniuose ančiuose, nosiaryklèje, plaučiuose ir kitose retose srityse [1]. Dažniausiai meningiomos būna solitarinès, bet 5-40 \% atvejų nustatomi daugybiniai navikai, tai ypač būdinga II tipo neurofibromatozei [4].

KT ir MRT vaizduose matomi tipiniai meningiomos požymiai leidžia gana patikimai nustatyti diagnozę. Šie požymiai yra būdingi dažniausiai pasitaikantiems nepikty- 


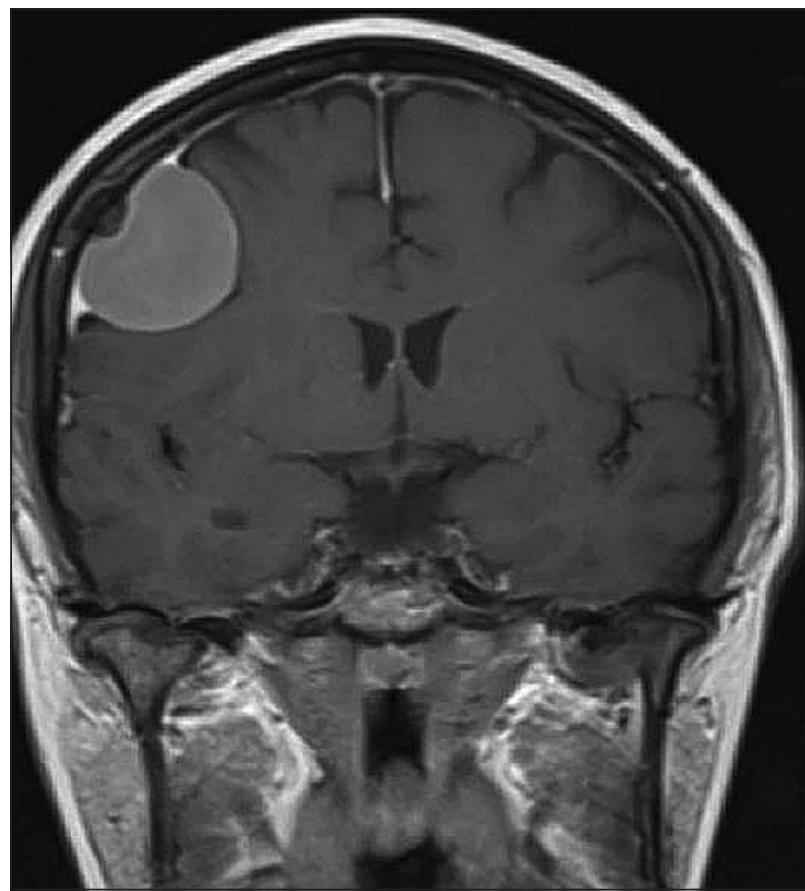

9 pav. Meningioma konveksitaliai.

MRT T1 su k/m seka, koronarinis pjūvis [3].

biniams histologiniams variantams, tačiau dalis jų randama ir retų piktybinių meningiomų atveju [10]. Remiantis radiologiniais vaizdais, sunku prognozuoti meningiomos histologinę diferenciaciją, tačiau kai kurie požymiai leidžia ịtarti naviką esant piktybinị [3].

MRT su gadolinio kontrastine medžiaga $(\mathrm{k} / \mathrm{m})$ yra geriausias vaizdinimo metodas meningiomoms diagnozuoti. Jis leidžia tiksliau diferencijuoti skirtingus minkštųjų audi-

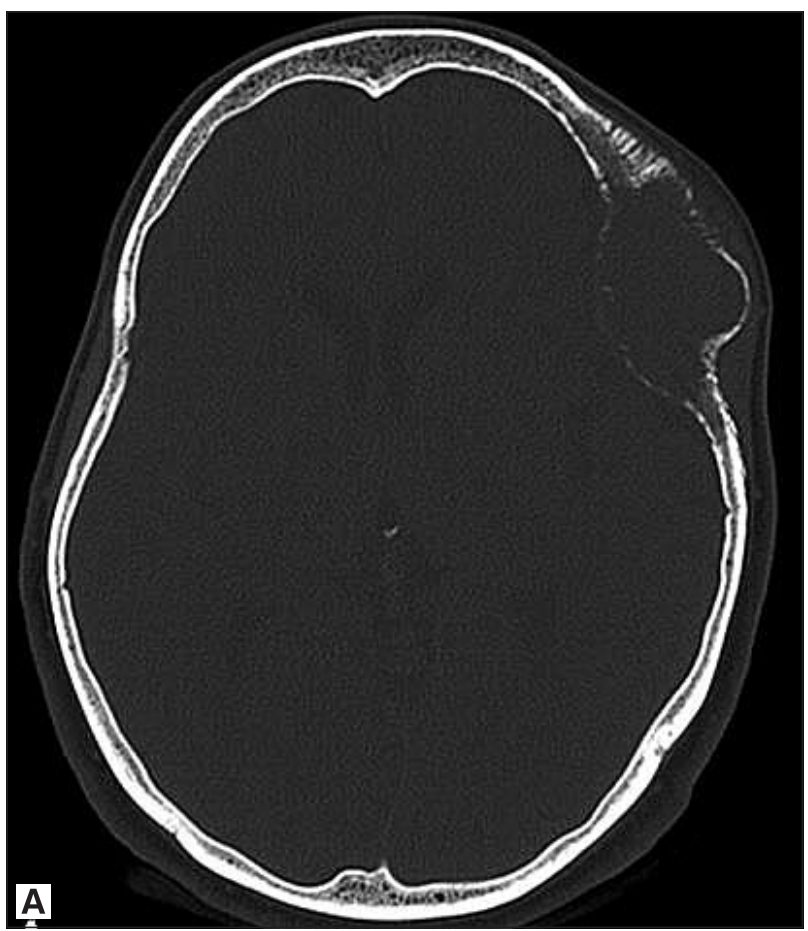

11 pav. Intraosalinė meningioma.

KT (A) ir MRT (B) vaizdai, aksialiniai pjūviai [30].

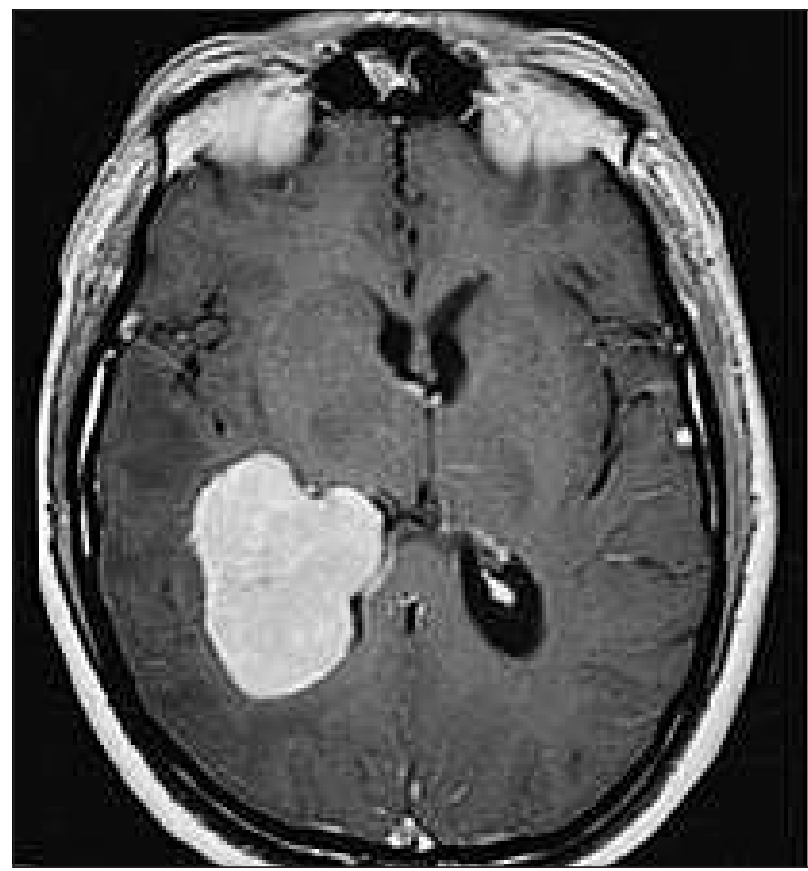

10 pav. Intraventrikulinė meningioma.

MRT T1 su k/m seka, aksialinis pjūvis [29].

nių tipus, tiksliau ịvertinti darinio santykị su smegenų parenchima (intra- ar ekstraaksialinè lokalizacija) bei kitomis anatominėmis struktūromis, ypač tinka analizuojant jukstaseliarinę sritị ir užpakalinę kaukolès duobę [11]. Lyginant su MRT, KT yra plačiau prieinamas tyrimas, labiau tinkantis urgentinių būklių atveju, kai reikalingas greitas skenavimas. KT tiksliau nei MRT leidžia ịvertinti kaulinị audinị ir kalcifikaciją. Kai pacientas turi kontraindikacijų MRT tyrimui, kaip alternatyva gali būti atliekama KT.

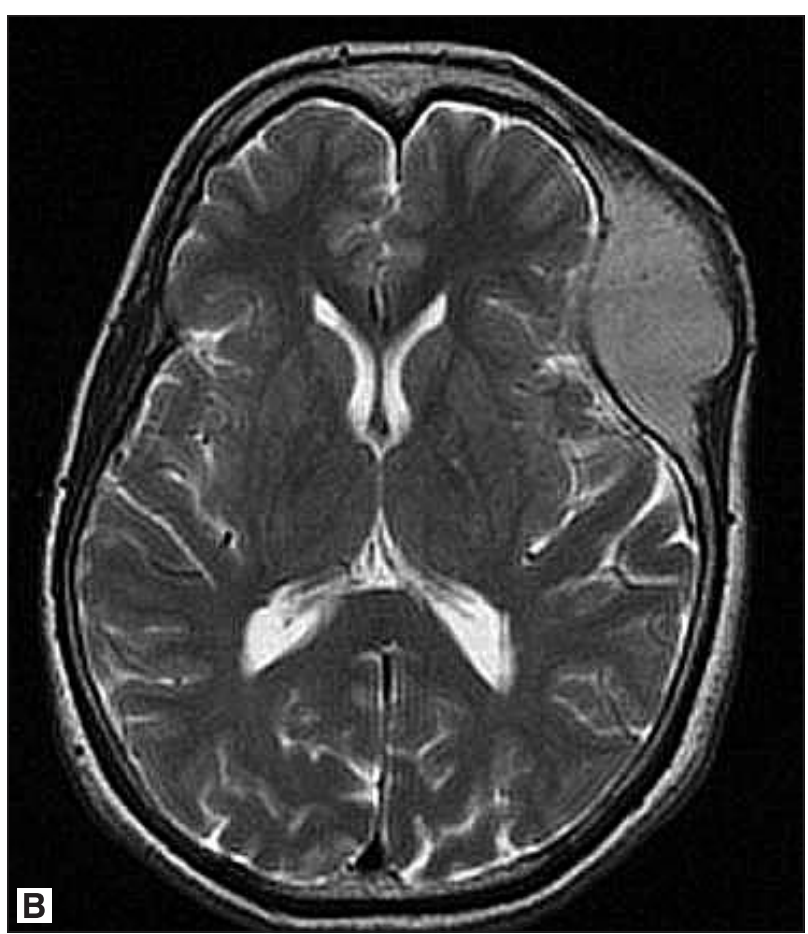



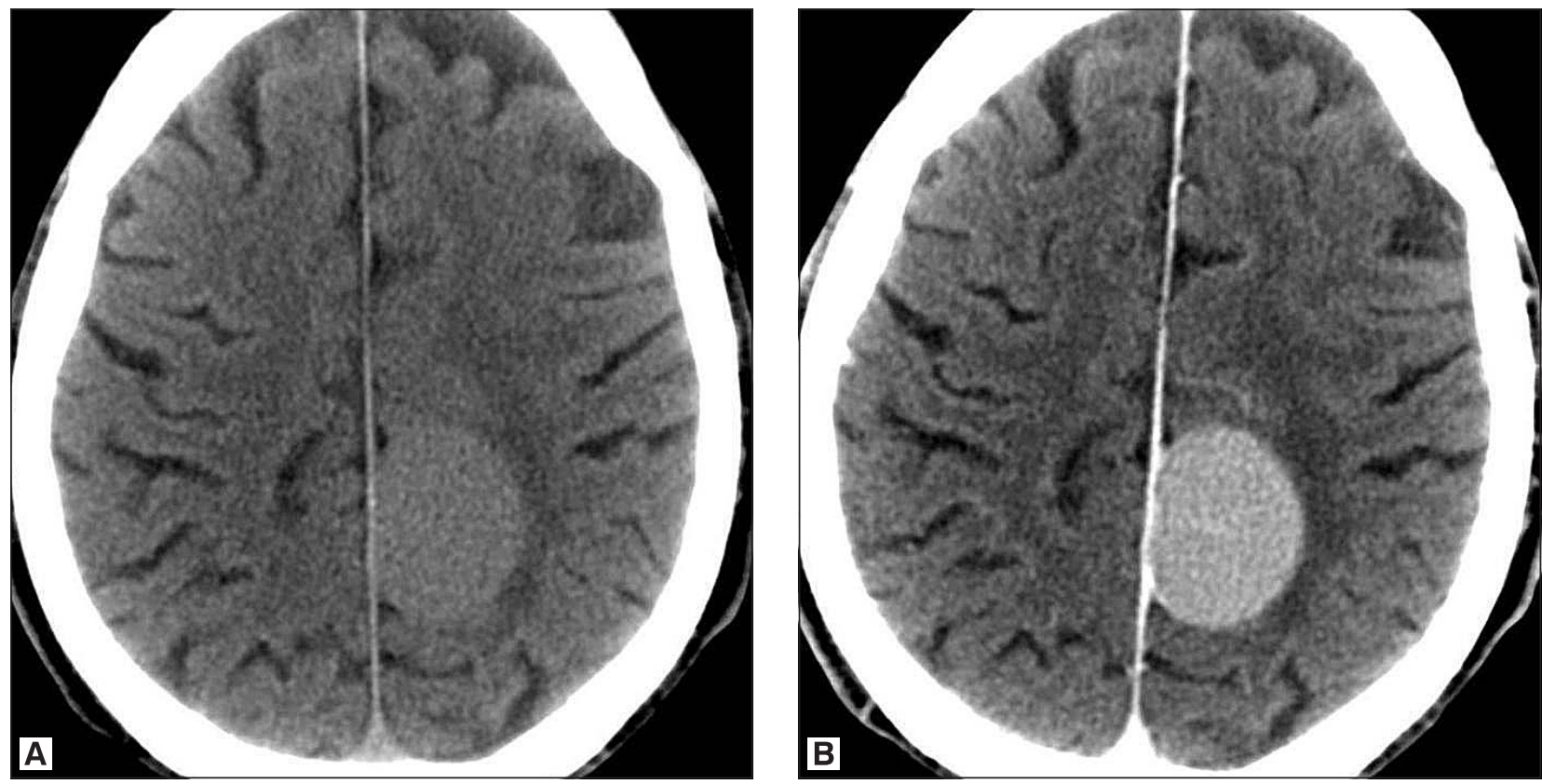

12 pav. Parasagitalinė meningioma su nežymia perifokaline edema.

KT be (A) ir su k/m (B), aksialinių pjūvių vaizduose matomas platus darinio kontaktas su kietuoju dangalu [31].

\section{Nepiktybinė meningioma (I laipsnio pagal PSO)}

Natyviniuose KT vaizduose intrakranijinės meningiomos tipiniai požymiai yra ekstraaksialinis darinys aiškiomis ribomis, lygiu kontūru, plačiu pagrindu kontaktuojantis su kietuoju dangalu (12 pav.). Jo forma paprastai yra apvali ar ovali, tačiau navikas gali nusitęsti palei kietajį dangalą, sudarydamas plokštelę (dažniausiai ties pleištakaulio mažuoju sparnu ar konveksitaliai) (13 pav.) [1,2]. Jei darinys yra gana didelis, jis spaudžia greta esančią smegenų žievę ir sukelia jos dislokaciją [3].

Meningioma gali sukelti aplinkinės smegenų parenchimos vazogeninę edemą, kuri KT vaizduose matoma kaip hipodensinè zona perifokaliai (12 pav.), tačiau dèl lèto naviko augimo šis požymis randamas tik apie $50 \%$ atvejų [11].

Maždaug ketvirtadaliui pacientų meningioma sukelia greta esančio kaulo sustorèjimą (hiperostozę), paprastai kaukolès skliauto kauluose ar pleištakaulio sparnuose (13, 14 pav.) [3]. Hiperostozè gali būti reakcinè arba susijusi su naviko invazija ị kaulą. Kartais tai diferencijuoti yra sudètinga, tačiau naviko invaziją leidžia įtarti intensyvus $\mathrm{k} / \mathrm{m}$ kaupimasis hiperostozės srityje [12]. Osteolizė yra būdingesnè piktybinèms meningiomoms, tačiau ją gali sukelti ir nepiktybiniai navikai. Dariniui augant priekineje kaukolès duobẻje, gali išsivystyti prienosinių ančių išsiplètimas (pneumosinus dilatans) [12].

MRT vaizduose T1 sekoje meningioma atrodo kaip hipo- ar izointensinio signalo, lyginant su smegenų žieve, T2 sekoje - izo- ar hiperintensinio signalo darinys (14 pav.). Ekstraaksialinę jo lokalizaciją rodo tarp darinio ir smegenų parenchimos T2 sekoje matoma hiperintensinio signalo likvoro juosta (15 pav.), tačiau ji nustatoma ne visais atvejais [12]. Minètoje likvoro juostoje gali būti matomos tarp naviko ir žievės suspaustos žievès kraujagyslès.
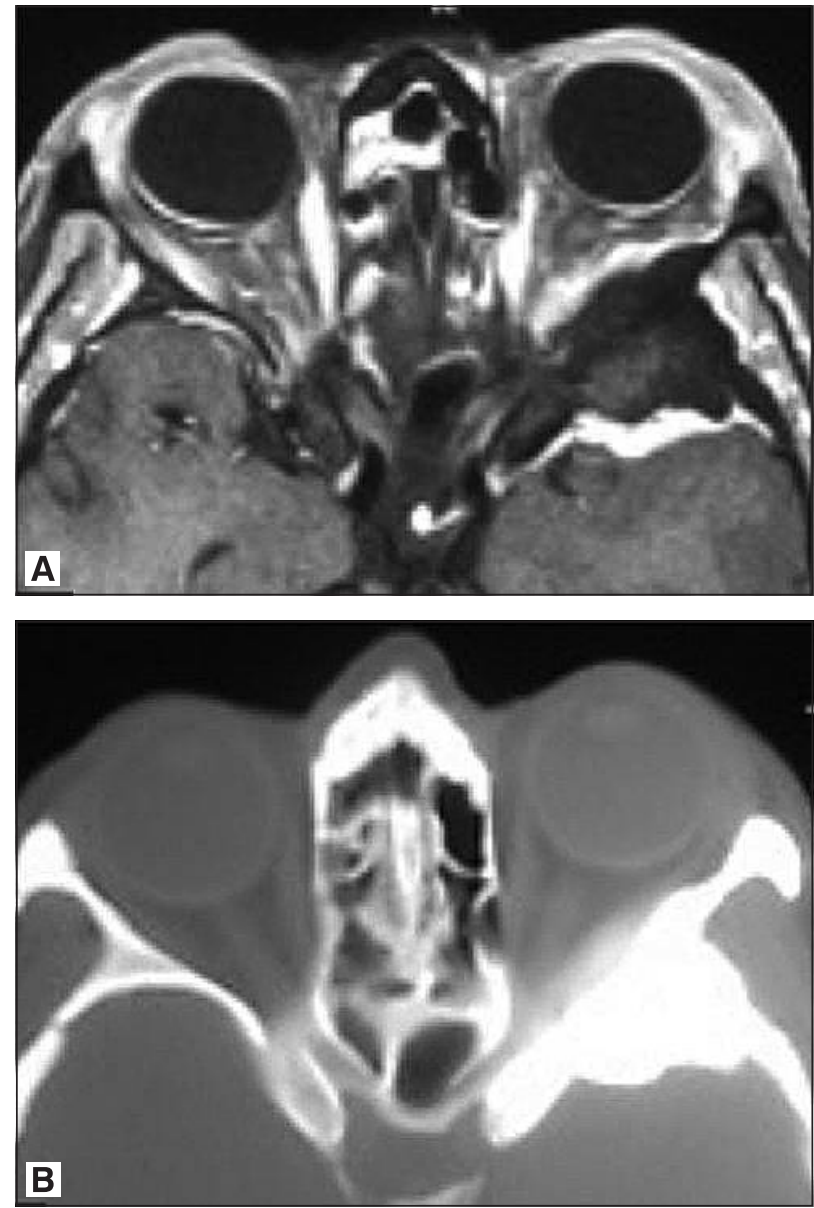

13 pav. Plokštelès formos meningioma pleištakaulio kairiajame sparne.

A - MRT T1 su k/m seka, B - KT aksialiniuose pjūviuose matoma kaulo hiperostozė [32]. 

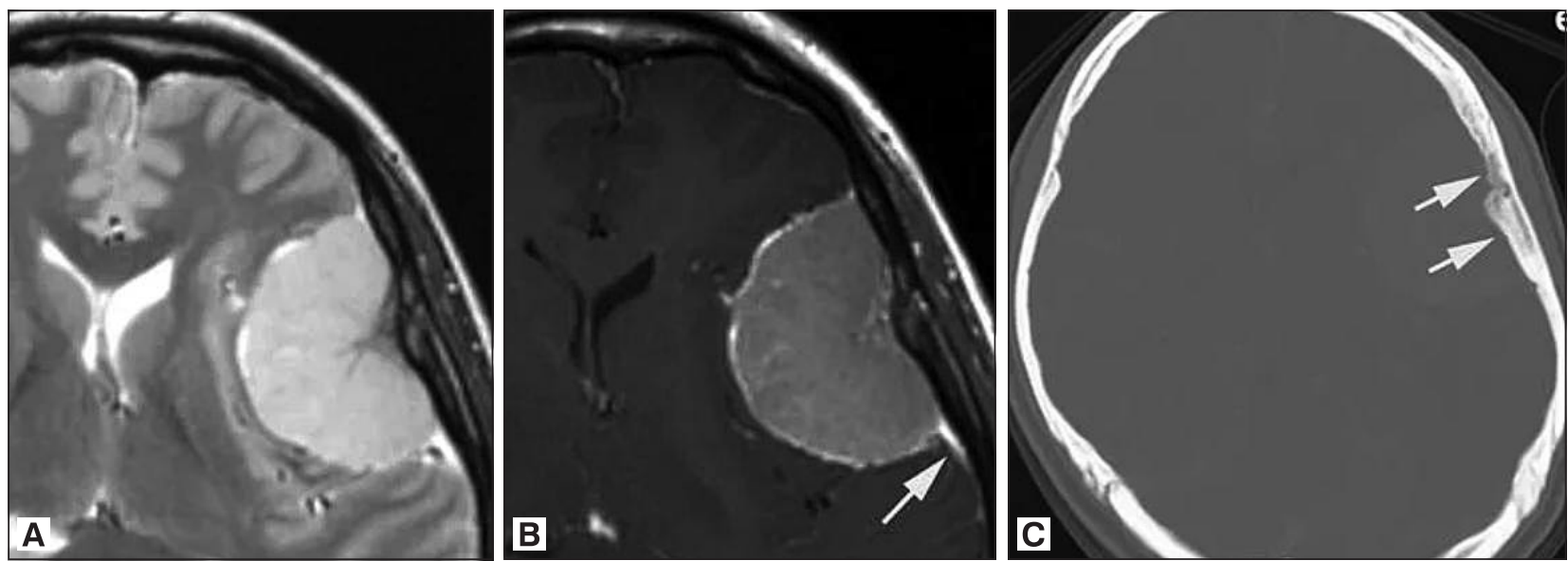

14 pav. Meningioma konveksitaliai.

A - MRT T2 sekoje matomas hiperintensinis darinio signalas, B - „kietojo dangalo uodegos“ požymis MRT T1 sekoje su k/m, C - KT matoma kaulo hiperostozė (rodyklè), aksialiniai pjūviai [10].

Meningiomos sukeliama aplinkinio audinio edema (T2 sekoje perifokalinė hiperintensinė zona) silpnai koreliuoja su naviko dydžiu ir nepiktybinio darinio atveju retai būna susijusi su naviko invazija ị šį audinị [2].

Daugumai nepiktybinių meningiomų padidejusi difuzijos restrikcija nėra būdinga, tačiau kontrolinio MRT tyrimo metu difuzijos sekose nustatomos dinamikoje sumažèjusios ADC vertės turètų kelti ịtarimą dèl naviko transformacijos ị didesni piktybiškumo laipsnị [13].

Meningiomoms yra būdingas intensyvus, homogeniškas k/m kaupimas, tačiau dẻl nekrozès zonų kalcinatų kaupimas gali būti ir heterogeniškas (dažniau piktybinių meningiomų atveju) [2]. Iki $72 \%$ navikų kontrastinèse sekose išryškejja „kietojo dangalo uodegos" požymis - šalia naviko esančio smegenų dangalo sustorèjimas (14 pav.). Tai

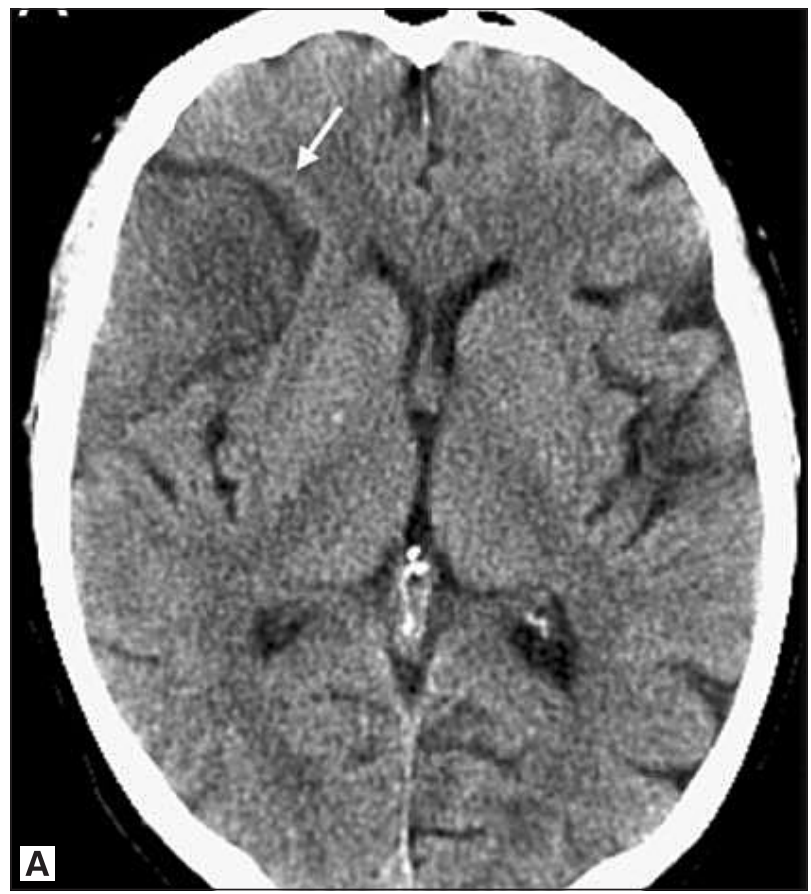

yra nespecifinis požymis, būdingas ir kitiems kietajame dangale augantiems navikams, leidžiantis patvirtinti ekstraaksialinę darinio lokalizaciją [12]. Šis požymis gali atspindėti reakcinius dangalo pokyčius, navikinę infiltraciją arba abu minètus procesus [13].

Kaukolès pamato srityje susiformavusios meningiomos potencialiai gali kontaktuoti ir augdamos apsupti intrakranijines kraujagysles, sukelti jų spindžio siaurinimą. Tačiau meningiomų sukeliamų smegenų kraujotakos sutrikimų dažnis yra labai mažas, literatūroje aprašyti tik keli atvejai $[1,14]$. Daug dažniau pasitaiko naviko invazija i kietojo dangalo ančius (ypač viršutinị strèlinị antị), dèl kurios gali išsivystyti jų dalinė ar visiška okliuzija [1].

Magnetinio rezonanso spektroskopija (MRS) gali padèti meningiomą diferencijuoti nuo kitų navikų. Menin-

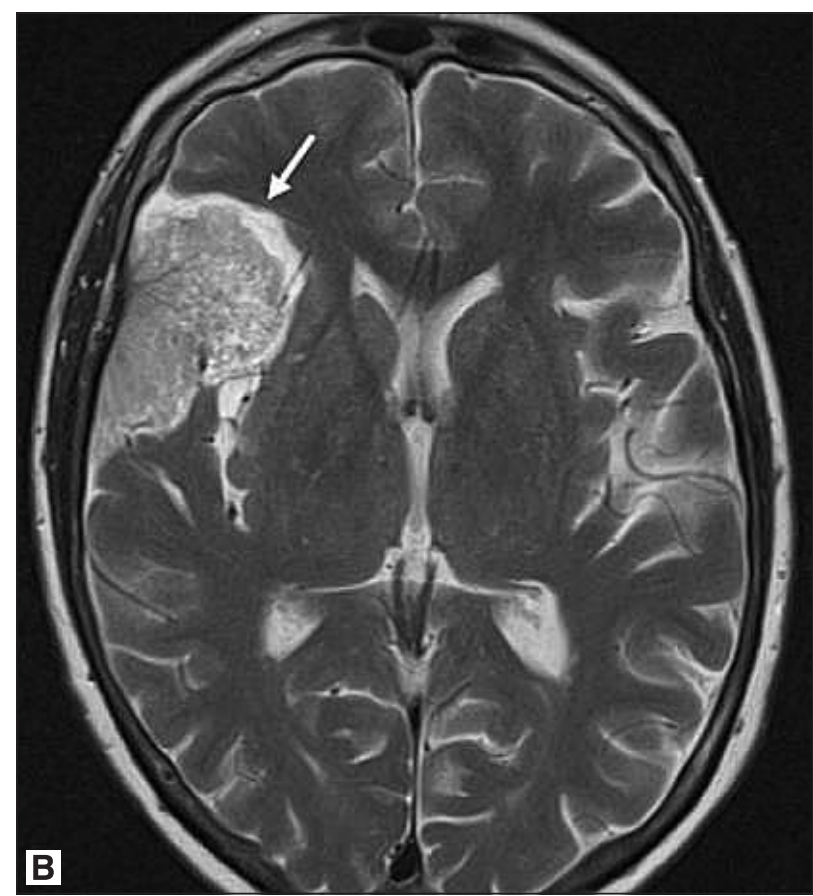

15 pav. Likvoro juosta tarp meningiomos ir aplinkinio smegenų audinio (rodyklè). A - KT, B - MRT T2 seka, aksialiniai pjūviai [12]. 

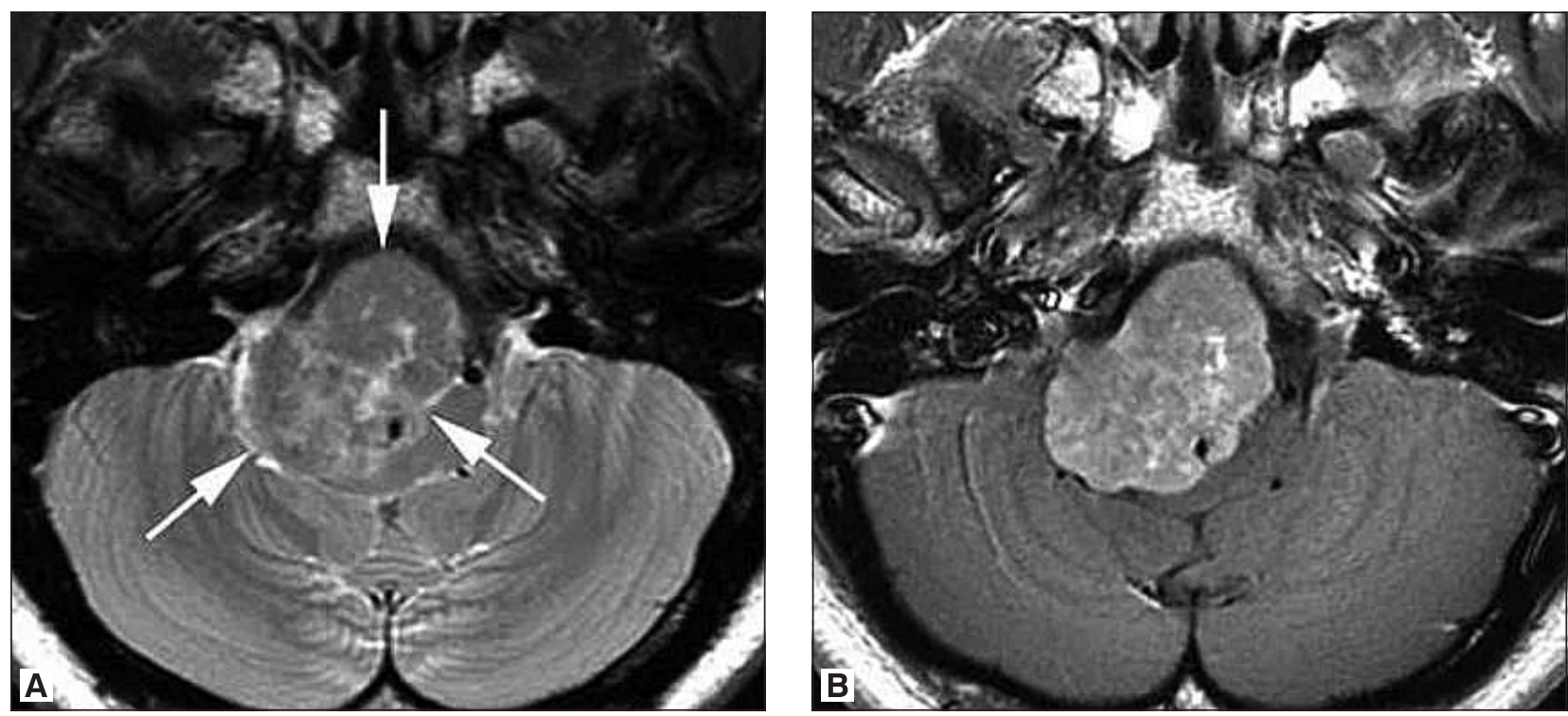

16 pav. Šviesių ląstelių meningioma.

MRT T2 (A) ir T1 su k/m (B) sekų aksialinių pjūvių vaizduose matomas netaisyklingos formos, nehomogeniškos struktūros, netolygiai $\mathrm{k} / \mathrm{m}$ kaupiantis darinys [10].

giomai būdingi šio tyrimo radiniai yra padidejusi cholino koncentracija, sumažejusi $\mathrm{N}$-acetilaspartato ir kreatino koncentracija (nespecifiniai požymiai, būdingi ir daugeliui kitų navikų), taip pat ryškiai padidejjusi alanino koncentracija (daugiau nei kituose navikuose, todèl šis požymis padeda identifikuoti meningiomą) [1, 3].

\section{Piktybinė meningioma (II, III laipsnio pagal PSO)}

Su piktybine meningiomos histologine diferenciacija ir agresyvesne ligos eiga siejama netaisyklinga darinio forma (16 pav.), nelygus kontūras, neryški riba tarp darinio ir aplinkinio smegenų audinio (17 pav.) [15]. T2 sekoje matomas hiperintensinis darinio signalas rodo minkštą jo konsistenciją, kuri labiau būdinga piktybinėms ir meningotelinėms (I laipsnio pagal PSO) meningiomoms [12]. Piktybinių meningiomų atveju, dažniau nei nepiktybinių, pasitaiko heterogeniška naviko struktūra dèl cistinių intarpų, hemoragijos, nekrozès zonų (18 pav.) [13]. Pastebėta, kad II laipsnio meningiomos dažniausiai lokalizuojasi ties kaukolès skliautu, o ne pamate [3].

Kalcinatų nebuvimas darinyje koreliuoja su piktybine histologine diferenciacija $[12,16]$, tačiau kai kurių piktybinių meningiomų atveju navike gali susiformuoti distrofiniai ar metaplaziniai kalcinatai (pagal R. Y. Hung ir kt., stebimi 15-20 \% KT atvejų) [12].

Esant piktybinès meningiomos invazijai ị smegenų parenchimą, nebus matoma naviką nuo jos atskirianti likvoro juosta [12]. Šios juostos nebuvimas ir neaiškios naviko ribos, nelygus kontūras koreliuoja su jo sukeliama perifokaline edema, todèl pasiūlyta hipotezè, kad, šiems požymiams esant kartu, edemos išsivystymo priežastis yra naviko penetracija ị smegenų parenchimą [17]. Perifokalinė edema gali išsivystyti ir dẻl kitų mechanizmų (hematoencefalinio barjero pažeidimo dèl kompresinès išemijos, venų obstrukcijos, navikinių ląstelių išskiriamų edemą suke- liančių medžiagų), todèl šis požymis neleidžia patikimai diferencijuoti piktybinių ir nepiktybinių meningiomų [12].

Kaip ir I laipsnio, pagal PSO, navikai, piktybinès meningiomos gali sukelti greta esančio kaulo hiperostozę ar osteolizę (18 pav.). Pastaroji tarp jų nustatoma dažniau, bet iš esmès yra retai aptinkamas požymis (3\% atvejų) [18]. Kai kuriais atvejais hiperostozė ir kaulo destrukcija gali išsivystyti kartu (būdinga $33 \%$ rabdoidinių meningiomų) [10].

Keliose studijose nustatyta, kad difuzijos sekose piktybinių meningiomų ADC vertès yra statistiškai patikimai mažesnès nei nepiktybinių (pagal B. Yin ir kt., vidutiniškai $0,85 \pm 0,17 \times 10^{-3} \mathrm{~mm}^{2} / \mathrm{s}$ ir $0,97 \pm 0,21 \times 10^{-3} \mathrm{~mm}^{2} / \mathrm{s}$ atitinka-

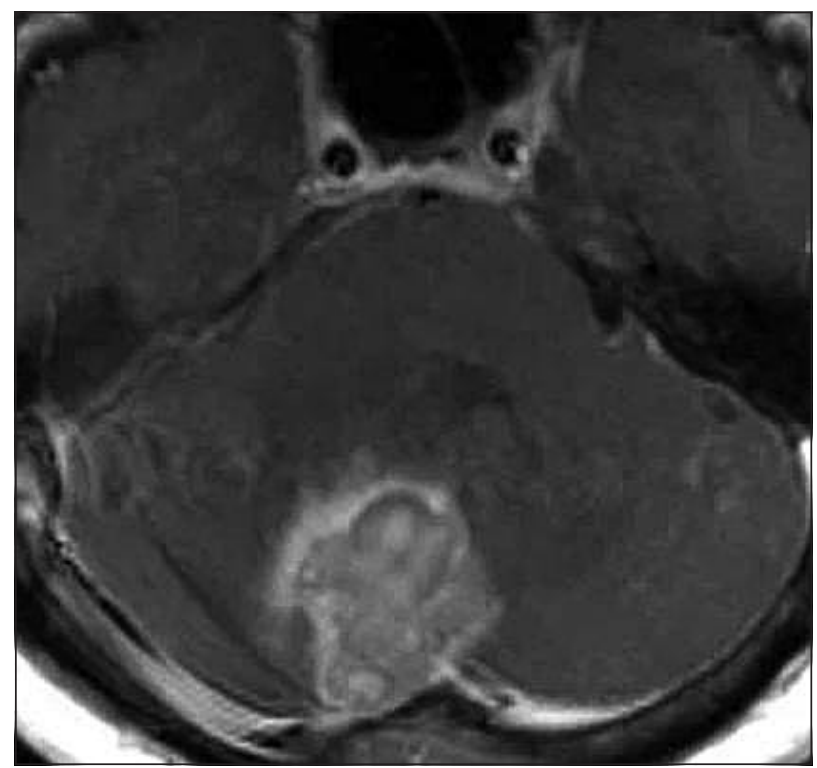

17 pav. Meningioma smegenèlių srityje.

MRT T1 su k/m aksialiniame pjūvyje matoma neryški riba tarp darinio ir aplinkinio smegenų audinio [10]. 

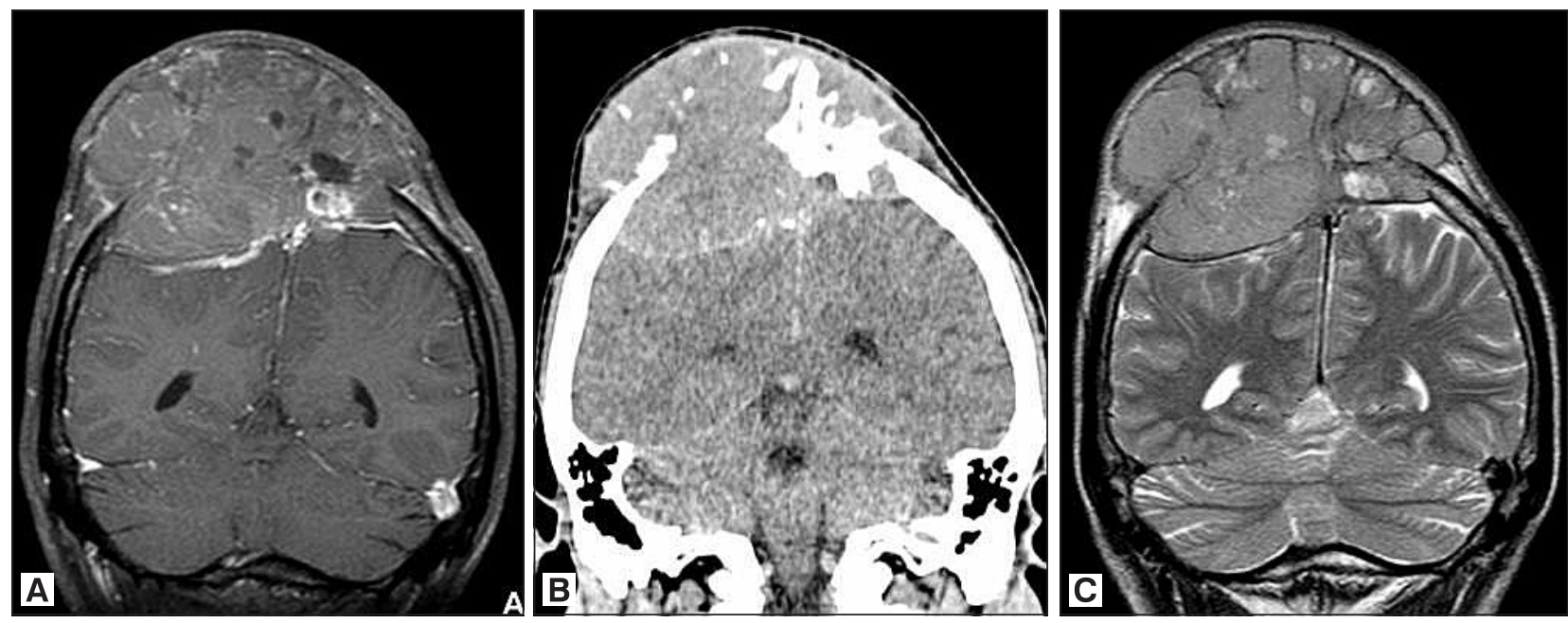

18 pav. III laipsnio, pagal PSO, meningioma.

MRT T1 su k/m sekos (A), KT (B), MRT T2 sekos (C) koronariniuose pjūviuose matoma kaulo destrukcija ir invazija ị poodinius minkštuosius audinius [2].

mai) $[17,20]$. Tačiau kiti autoriai statistiškai patikimo ADC skirtumo tarp nepiktybinių ir piktybinių meningiomų ar tarp skirtingų jų histologinių variantų nenustatė [13, 20].

Dèl darinyje esančių cistinių intarpų, hemoragijos, nekrozės zonų kontrastinėse sekose jis gali atrodyti heterogeniškas (19 pav.). M. Wen su bendraautoriais nustatė, kad beveik 2/3 meningiomų atvejų $\mathrm{k} / \mathrm{m}$ kaupiantis kietojo dangalo sustoréjimas šalia naviko (,kietojo dangalo uodegos“ požymis) būna infiltruotas navikinių ląstelių, kurios taip pat gali būti mikroskopiškai išplitusios ir už dangalo ribų [21]. Tačiau „kietojo dangalo uodegos“ požymis gali atspindèti tik reakcinius dangalo pokyčius.

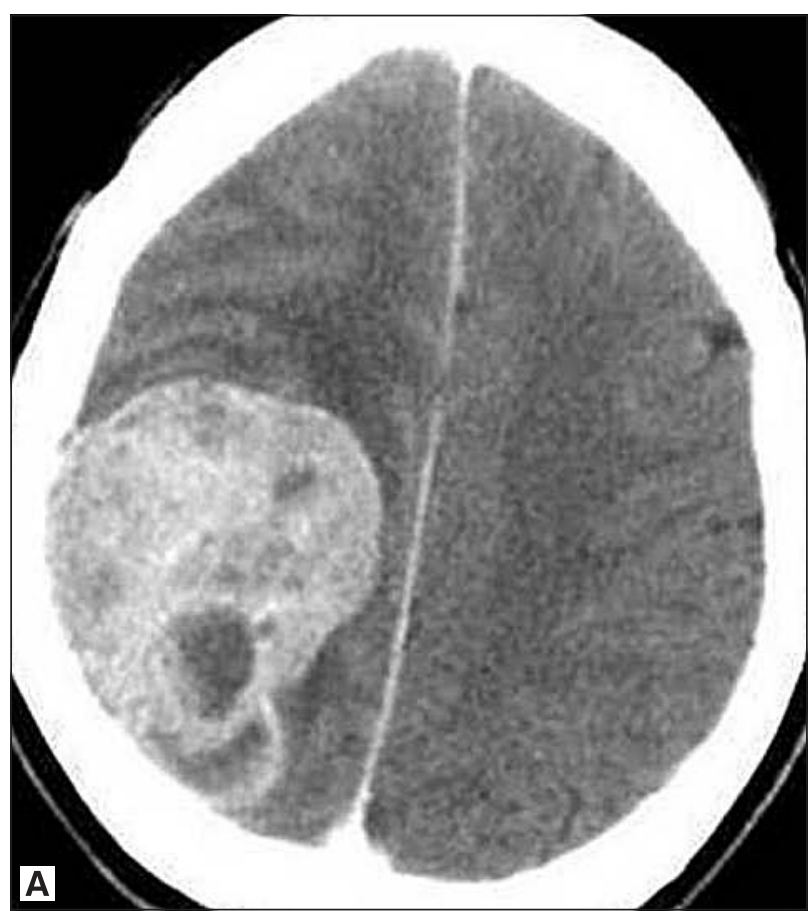

Nors MRS neleidžia patikimai atskirti skirtingo piktybiškumo laipsnio meningiomų, L. A. Tan ir kt. tyrime pastebėta, kad navikai, turintys didesnic cholino / kreatino santyki $(8,8$ ir 5,1), dažniau būna II ar III laipsnio, pagal PSO [17].

\section{Gydymas ir ligos eiga}

Asimptomėms, atsitiktinai nustatytoms, mažoms meningiomoms ( $<2 \mathrm{~cm}$ diametro [22]) gydymas nereikalingas, šiuo atveju pasirenkama stebejjimo taktika, periodiškai atliekant vaizdinimo tyrimus. Tačiau simptominėms, dinamikoje didejjančioms ir sukeliančioms gretimų anatominių

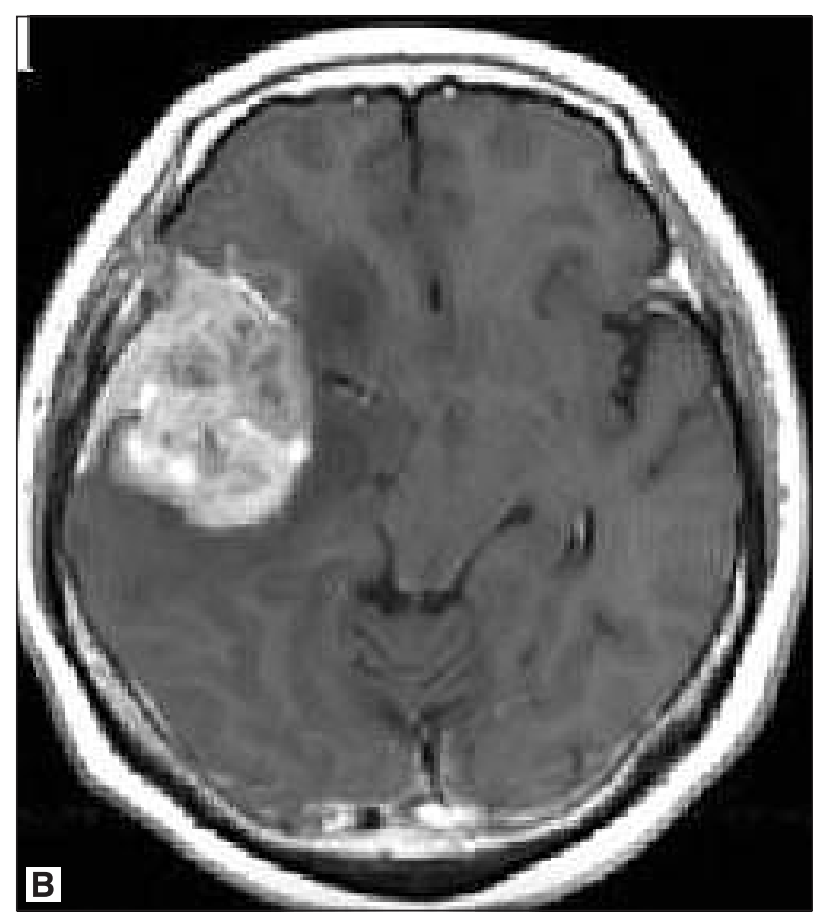

19 pav. Heterogeniškas k/m kaupimas navike.

Skirtingų pacientų KT (A) ir MRT T1 sekos su k/m (B) vaizdai, aksialiniai pjūviai [31, 33]. 
struktūrų pažeidimo riziką, piktybinei histologinei diferenciacijai būdingais radiologiniais požymiais pasižyminčioms meningiomoms taikomas operacinis gydymas, pasirinkimo metodas - totalinè chirurginè rezekcija [23]. Dauguma meningiomų šiuo metodu išgydomos efektyviai, nors kartais taikoma ir adjuvantinė spindulinė terapija: paprastai piktybinių ar recidyvavusių meningiomų atveju ar kai totalinė rezekcija negalima dèl tam nepalankios naviko lokalizacijos, vietinio išplitimo, todèl navikas pašalinamas iš dalies [24]. Nerezektabiliems navikams ar pacientams, kuriems operacija kontraindikuotina, spindulinè terapija yra pirminis gydymo metodas [25].

Po operacijos gali recidyvuoti visų diferenciacijos laipsnių meningiomos, bet dažniau tai pasitaiko piktybinių navikų atveju. Literatūroje nurodoma, kad per 10 metų recidyvuoja 20-75 \% II laipsnio ir 50-94 \% III laipsnio meningiomų, nepaisant agresyvios gydymo taktikos [12, 26]. Patikimiausias recidyvo prognostinis veiksnys yra operacijos radikalumas. Taip pat pastebėta, kad dažniau recidyvuoja daugybinės meningiomos [2, 8]. Tarp I laipsnio navikų recidyvas pasitaiko 7-25\% atvejų [3]. Meningioma gali progresuoti ị didesnio piktybiškumo laipsnị: tai nustatoma iki $2 \%$ nepiktybinių ir apie $30 \%$ recidyvavusių navikų [27].

Meningiomos metastazuoja retai ( $<0,2 \%$ visų atvejų). Tai yra daugiau būdinga piktybinès diferenciacijos navikams (apie 40 \% III laipsnio navikų), bet literatūroje aprašyta ir nepiktybinių meningiomų metastazavimo atvejų [8]. Tikslus metastazavimo būdas nèra žinomas, tačiau manoma, kad tai - hematogeninis kelias per paravertebrini (Batsono) venini rezgini, nes $75 \%$ metastazavusios meningiomos atvejų nustatoma naviko invazija ị veninị antị. Dažniausios metastazių vietos - plaučiai ir intraabdominaliniai organai [8].

\section{APTARIMAS}

Aprašytame klinikiniame atvejyje pacientei intrakranijinė meningioma rasta konveksitaliai (dešinės kaktinès skilties srityje). Literatūroje ši lokalizacija nurodoma kaip pasitaikanti dažniausiai [1]. Taip pat pastebèta, kad II laipsnio, pagal PSO, meningiomos dažniausiai lokalizuojasi ties kaukolès skliautu [2]. Pirmųjų KT ir MRT tyrimų natyviniuose vaizduose navikas buvo kiek nehomogeniškos struktūros, po intraveninio kontrastavimo netolygiai kaupẻ k/m dèl nekrozès zonų. Šie požymiai yra būdingesni piktybinèms meningiomoms, bet nustatomi ir $15 \%$ nepiktybinių navikų atvejų [12]. Kitų radiologinių požymių, leidžiančių įtarti meningiomos piktybinị histologinį variantą (netaisyklingos darinio formos, nelygaus kontūro, neryškios ribos tarp darinio ir aplinkinio smegenų audinio), ar kaulinio audinio pokyčių nebuvo matoma.

Pacientei diagnozuota atipinè meningioma pasižymi polinkiu recidyvuoti (per 10 metų recidyvuoja 20-75\% [3]), tai ir buvo nustatyta po 10 mèn. nuo pirmos operacijos. Tuomet atliktos MRT vaizduose recidyvavusio dari- nio struktūra buvo homogeniška, tačiau forma - netaisyklinga, kontūras - nelygus, t. y. požymiai, koreliuojantys su naviko piktybine histologine diferenciacija. Stebètas darinio kontaktas su viršutinio strèlinio ančio kraštu, tačiau invazijos į antị požymių nebuvo matoma.

Aprašytame atvejyje navikas pasižymejjo tik keliais ir neišreikštais piktybinėms meningiomoms būdingais požymiais, neleidžiančiais prognozuoti histologinès diferenciacijos laipsnio. Tai būtų galima daryti nustatant daugiau su atipine ar anaplazine histologija siejamų požymių, tačiau galimybès tiksliai nustatyti meningiomos piktybiškumo laipsnị radiologiniai tyrimai nesuteikia [1].

\section{Literatūra}

1. Watts J, Box G, Galvin A, et al. Magnetic resonance imaging of meningiomas: a pictorial review. Insights Imaging 2014; 5(1): 113-22. https://doi.org/10.1007/s13244-013-0302-4

2. Freitas LDA, Manzella A, Figueiredo H, et al. Imaging features of intracranial meningiomas with histopathological correlation. Plakatas pristatytas: Europos radiologijos kongresas; 2017 kovo 1-5 d.; Viena, Austrija. https://doi.org/ 10.1594/ecr2017/C-2498

3. Lyndon D, Lansley JA, Evanson J, et al. Dural masses: meningiomas and their mimics. Insights Imaging 2019; 10: 11. https://doi.org/10.1186/s13244-019-0697-7

4. Korhonen K. Pathological and epidemiological aspects of meningioma [academic dissertation]. University of Tamper, 2012 [cited 2020 Mar 10]. Available from: https://trepo.tuni.fi/bitstream/handle/10024/66884/ 978-951-44-8764-4.pdf?sequence=1\&isAllowed=y

5. Kshettry VR, Ostrom QT, Kruchko C, et al. Descriptive epidemiology of WHO grades II and III intracranial meningiomas in the United States. Neuro-Oncology 2015; 17(8): 1166-73. https://doi.org/10.1093/neuonc/nov069

6. Fung KM. Meningiomas pathology. Medscape [Internet]. 2014 [cited 2020 Mar 1]. Available from: https://emedicine.medscape.com/article/1744164overview\#a3

7. Wiemels J, Wrensch M, Claus EB. Epidemiology and etiology of meningioma. J Neurooncol 2010; 99(3): 307-14. https://doi.org/10.1007/s11060-010-0386-3

8. Beutler BD, Nguyen ET, Parker RA, et al. Metastatic meningioma: case report of a WHO grade I meningioma with liver metastases and review of the literature. Radiol Case Rep 2020; 15(2): 110-6. https://doi.org/10.1016/j.radcr. 2019.10.027

9. Haddad G. Meningioma clinical presentation. Medscape [Internet]. 2018 [cited 2020 March 3]. Available from: https://emedicine.medscape.com/article/1156552clinical\#b1

10. Kunimatsu A, Kunimatsu N, Kamiya K, et al. Variants of meningiomas: a review of imaging findings and clinical features. Jpn J Radiol 2016; 34: 459-69. https://doi.org/ 10.1007/s11604-016-0550-6

11. Islam O, Hall GJ. Brain meningioma imaging. Medscape [Internet]. 2016 [cited 2020 Mar 6]. Available from: https://emedicine.medscape.com/article/341624overview\#a3

12. Huang RY, Bi WL, Griffith B, et al. Imaging and diagnostic advances for intracranial meningiomas. Neuro-Oncology 2019; 21: 44-61. https://doi.org/10.1093/neuonc/noy143 
13. Saloner D, Uzelac A, Hetts S, et al. Modern meningioma imaging techniques. J Neurooncol 2010; 99(3): 333-40. https://doi.org/10.1007/s11060-010-0367-6

14. Heye S, Maleux G, Van Loon J, et al. Symptomatic stenosis of the cavernous portion of the internal carotid artery due to an irresectable medial sphenoid wing meningioma. Am J Neuroradiol 2006; 27(7): 1532-4.

15. Hashiba T, Hashimoto N, Maruno M, et al. Scoring radiologic characteristics to predict proliferative potential in meningiomas. Brain Tumor Pathol 2006; 23(1): 49-54. https://doi.org/10.1007/s10014-006-0199-4

16. Girgždytė K. Sąsajų tarp galvos smegenų meningiomų piktybiškumo bei recidyvavimo ir neuroradiologinių duomenų tyrimas [magistro diplominis darbas]. Kaunas, Lietuvos sveikatos mokslų universitetas, 2016 [Žiūrèta 2020-03-24]. Prieiga per internetą: https://publications.lsmuni.lt/object/ elaba:16025151/16025151.pdf

17. Tan LA, Boco T, Johnson AK, et al. Magnetic resonance imaging characteristics of typical and atypical/anaplastic meningiomas - case series and literature review. $\mathrm{Br} \mathrm{J}$ Neurosurg 2015; 29(1): 77-81. https://doi.org/10.3109/ 02688697.2014 .957647

18. Gangadhar K, Santhosh D, Fatterpekar GM. Imaging features of intracranial meningiomas with histopathological correlation: a relook into old disease. NJR 2013; 3(1): 14-32. https://doi.org/10.3126/njr.v3i1.8713

19. Yin B, Liu L, Zhang BY, et al. Correlating apparent diffusion coefficients with histopathologic findings on meningiomas. Eur J Radiol 2012; 81(12): 4050-6. https://doi.org/10.1016/ j.ejrad.2012.06.002

20. Weber DC, Lovblad KO, Rogers L. New pathology classification, imagery techniques and prospective trials for meningiomas: the future looks bright. Curr Opin Neurol 2010; 23(6): 563-70. https://doi.org/10.1097/WCO. 0b013e328340441e

21. Wen M, Jung S, Moon KS, et al. Immunohistochemical profile of the dural tail in intracranial meningiomas. Acta Neurochir (Wien) 2014; 156(12): 2263-73. https://doi.org/ 10.1007/s00701-014-2216-4

22. Sughrue ME, Rutkowski MJ, Aranda D, et al. Treatment decision making based on the published natural history and growth rate of small meningiomas. J Neurosurg 2010; 113(5): 1036-42. https://doi.org/10.3171/2010.3. JNS091966

23. Chamoun R, Krisht KM, Couldwell WT. Incidental meningiomas. Neurosurg Focus 2011; 31(6): E19. https://doi.org/10.3171/2011.9.FOCUS11220

24. Goldbrunner R, Minniti G, Preusser M, et al. EANO guidelines for the diagnosis and treatment of meningiomas. Lancet Oncol 2016; 17(9): e383-91. https://doi.org/10.1016/S14702045(16)30321-7

25. Buerki RA, Horbinski CM, Kruser T, et al. An overview of meningiomas. Future Oncol 2018; 14(21): 2161-77. https://doi.org/10.2217/fon-2018-0006

26. Walcott BP, Nahed BV, Brastianos PK, et al. Radiation treatment for WHO grade II and III meningiomas. Front Oncol 2013; 3: 227. https://doi.org/10.3389/fonc.2013.00227
27. Al-Mefty O, Kadri PA, Pravdenkova S, et al. Malignant progression in meningioma: documentation of a series and analysis of cytogenetic findings. J Neurosurg 2004; 101: 210-8. https://doi.org/10.3171/jns.2004.101.2.0210

28. Harter PN, Braun Y, Plate KH. Classification of meningiomas - advances and controversies. Chin Clin Oncol 2017; 6(Suppl 1): S2. https://doi.org/10.21037/cco.2017.05.02

29. Majos C, Cucurella G, Aguilera C, et al. Intraventricular meningiomas: MR imaging and MR spectroscopic findings in two cases. Am J Neuroradiol 1999; 20(5): 882-5.

30. Agrawal V, Ludwig N, Agrawal A, et al. Intraosseous intracranial meningioma. Am J Neuroradiol 2007; 28(2): 314-5.

31. Fatahi Bandpey L, Sanchez Santos PJ, Yago D, et al. Diverse imaging appearances and locations of meningioma. Plakatas pristatytas: Europos radiologijos kongresas; 2013 kovo 7-11 d.; Viena, Austrija. https://doi.org/10.1594/ ecr2013/C-1616

32. Simas NM, Farias JPF. Sphenoid Wing en plaque meningiomas: surgical results and recurrence rates. Surg Neurol Int 2013; 4: 86. https://doi.org/10.4103/21527806.114796

33. Kawahara Y, Nakada M, Hayashi Y, et al. Prediction of high-grade meningioma by preoperative MRI assessment. J Neurooncol 2012; 108: 147-52. https://doi.org/10.1007/ s11060-012-0809-4

\section{R. Montvilaitė, S. R. Letautienė, R. Kvaščevičius, A. Barkauskiené}

\section{IMAGING FEATURES OF INTRACRANIAL MENINGIOMAS WITH HISTOPATHOLOGICAL CORRELATION: A CASE REPORT AND REVIEW OF LITERATURE}

\section{Summary}

Meningiomas are the most common non-glial tumours of the central nervous system. Most meningiomas are benign; however, $\sim 20 \%$ are associated with less favourable clinical outcomes and are considered malignant. It is important for the radiologist to distinguish between the benign and malignant features of meningiomas as they have different management strategies. Although the value of medical imaging (computed tomography, magnetic resonance imaging) in predicting the histopathologic grades of meningiomas is limited, certain features increase the probability of the lesion being malignant. In this article, we present a case report of a recurrent malignant intracranial meningioma and a literature review and analyze the correlations of the radiological characteristics of meningiomas with histopathological tumor differentiation.

Keywords: meningioma, computed tomography, magnetic resonance imaging, histology.

Gauta:

20200624

Priimta spaudai: 20200813 